OECD Science, Technology and Industry Working Papers 2009/09

The Emerging Patent Marketplace

\section{Tomoya Yanagisawa,} Dominique Guellec 
Organisation de Coopération et de Développement Économiques

Organisation for Economic Co-operation and Development

22-Dec-2009

DIRECTORATE FOR SCIENCE, TECHNOLOGY AND INDUSTRY

English - Or. English

\section{THE EMERGING PATENT MARKETPLACE}

STI WORKING PAPER 2009/9

Statistical Analysis of Science, Technology and Industry

Tomoya Yanagisawa and Dominique Guellec 


\section{STI Working Paper Series}

The Working Paper series of the OECD Directorate for Science, Technology and Industry is designed to make available to a wider readership selected studies prepared by staff in the Directorate or by outside consultants working on OECD projects. The papers included in the series cover a broad range of issues, of both a technical and policy-analytical nature, in the areas of work of the DSTI. The Working Papers are generally available only in their original language - English or French - with a summary in the other.

Comments on the papers are invited, and should be sent to the Directorate for Science, Technology and Industry, OECD, 2 rue André-Pascal, 75775 Paris Cedex 16, France.

The opinions expressed in these papers are the sole responsibility of the author(s) and do not necessarily reflect those of the OECD or of the governments of its member countries.

\section{www.oecd.org/sti/working-papers}

OECD/OCDE, 2009

Applications for permission to reproduce or translate all or part of this material should be made to: OECD Publications, 2 rue André-Pascal, 75775 Paris, Cedex 16, France; e-mail: rights@oecd.org 
DSTI/DOC(2009)9

\title{
THE EMERGING PATENT MARKETPLACE
}

\section{Tomoya Yanagisawa and Dominique Guellec}

Economic Analysis and Statistics Division

Directorate for Science, Technology and Industry (DSTI), OECD

Contact: tomoya.yanagisawa@oecd.org

\begin{abstract}
Facilitating the mobilisation, sharing, or exchange of patents is increasingly important to promote innovation in this globalised and well-networked world, where the circulation of ideas and technologies is essential to innovation. In the context of open innovation, patents are expected to play a role as a means for transferring ideas and technologies from one entity to another, in addition to acting as a means for excluding others from using companies' own ideas and technologies. In such a situation, a variety of new entities focusing on patent-related transactions are emerging. Some IP specialist firms seek to monetise patents by creating strategic patent portfolios and licensing them. Others provide websites to establish online marketplaces where patents and ideas could be traded. And still others establish a co-operative venture that buys and licenses patents to its members for defensive purpose. They also include IP investment banks that will lend against the value of IP, and firms that seek to create funds, similar to mutual funds, which allow investors to earn revenue from royalties. These new players now could significantly influence the circulation of patents. It would be important for governments to deepen their understanding of how these new players are performing in the patent transaction markets in order to support their development in the most socially beneficial directions. This may also be important for traditional technology-oriented companies, since the effective use of patent transaction markets will help them improve their innovation process and strengthen their competitiveness. Therefore, analysis of the functions, business models, and activities of IP specialist firms is the central topic of this research.
\end{abstract}

Key words: patent, IP, innovation, patent licence, technology market, IP market 


\title{
LE NOUVEAU MARCHÉ DES BREVETS
}

\author{
Tomoya Yanagisawa et Dominique Guellec
}

Division des analyses économiques et des statistiques

Direction de la science, de la technologie et de l'industrie (DSTI), OCDE

Contact: tomoya.yanagisawa@oecd.org

\begin{abstract}
RÉSUMÉ
De plus en plus, il est important de faciliter la mobilisation, le partage ou l'échange de brevets pour promouvoir l'innovation dans ce monde globalisé et très interconnecté, où la circulation des idées et des technologies est essentielle pour l'innovation. Dans l'optique de l'innovation ouverte, les brevets devraient jouer un rôle en tant que moyen de transfert d'idées et de technologies d'une entité à l'autre, tout en servant à empêcher que d'autres utilisent les idées et technologies appartenant aux entreprises. Dans ces conditions, il apparaît actuellement diverses entités nouvelles dont l'activité est axée sur les transactions relatives aux brevets. Certaines entreprises spécialisées en PI cherchent à monétiser des brevets en créant des portefeuilles de brevets stratégiques et en concédant les licences d'exploitation qui s'y rattachent. D'autres s'emploient à mettre en place sur des sites Web des marchés en ligne où les brevets et les idées pourraient faire l'objet d'échanges. D'autres encore constituent des coopératives qui achètent des brevets et cèdent les licences d'exploitation à leurs membres à des fins défensives. On voit aussi se créer des banques d'investissement spécialisées dans la PI, qui octroient des prêts en utilisant la valeur de la PI comme garantie, et des entreprises qui cherchent à créer des fonds, comparables à des fonds communs de placement, permettant aux investisseurs de tirer des revenus des redevances. Ces nouveaux acteurs pourraient exercer désormais une puissante influence sur la circulation des brevets. Il importe, pour les pouvoirs publics, de mieux connaître les comportements de ces nouveaux acteurs sur les marchés où s'opèrent les transactions sur les brevets afin de pouvoir favoriser un essor de ces marchés tendant vers ce qui sera optimal pour la collectivité. Il peut être important aussi pour les entreprises classiques à vocation technologique de bien appréhender ces évolutions, car l'utilisation des marchés des transactions concernant les brevets les aidera à améliorer leur processus d'innovation et à renforcer leur compétitivité. L'analyse des fonctions, des modèles économiques et des activités des entreprises spécialisées en PI constitue donc le thème central de cette recherche.
\end{abstract}

Mots clés: brevet, PI, innovation, licence de brevet, marché des technologies, marché de la PI 


\section{TABLE OF CONTENTS}

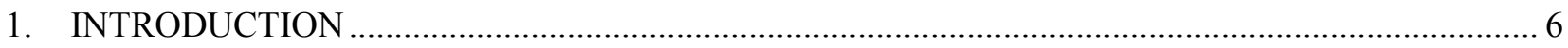

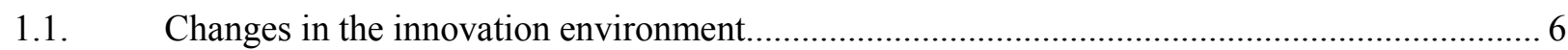

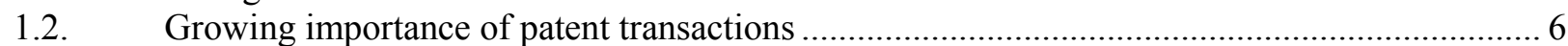

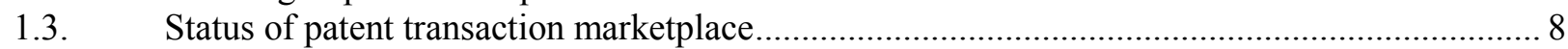

2. NEW PLAYERS AND ACTIVITIES IN THE PATENT TRANSACTION MARKET....................... 9

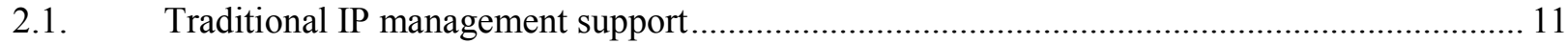

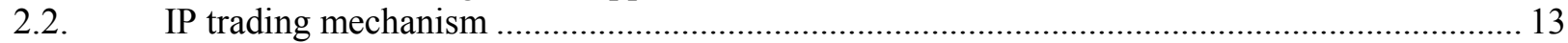

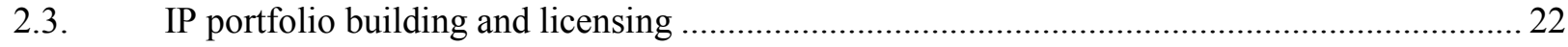

2.4. Defensive patent aggregation/Framework for patent sharing ............................................ 26

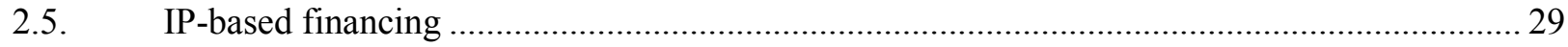

3. ACTIVITIES OF PUBLIC ORGANISATIONS FOR FOSTERING IP MARKETS ......................... 36

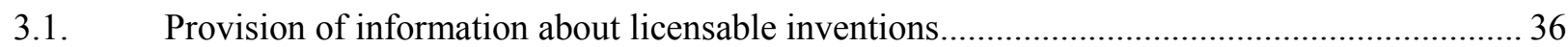

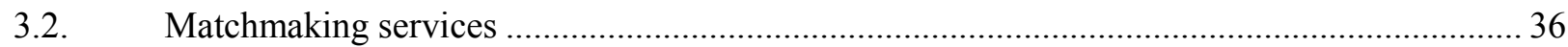

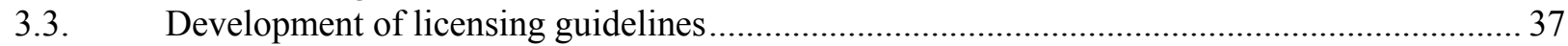

3.4. Clarification of regulations regarding patent licensing activities ........................................ 37

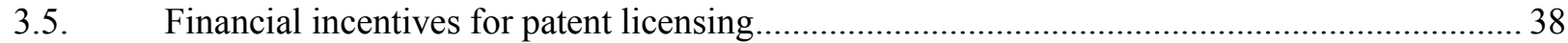

3.6. Improvement in the quality of patent rights at the global level ........................................... 39

3.7. Development of patent circulation/sharing platforms ............................................................. 39

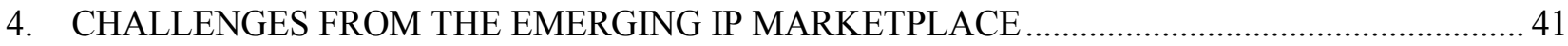

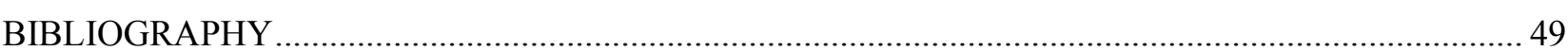




\section{INTRODUCTION}

\subsection{Changes in the innovation environment}

In recent years, the environment surrounding $R \& D$ activities has been dramatically changing. Due to the growing technological complexity and technological convergence, it is becoming difficult and inefficient for a company to develop all technologies and components required for providing new products or services by itself, particularly in areas like ICT and Life sciences. Given the innovations contained in a mobile phone today - camera, LCD screen, PDA system, web browsers, CPU chips - few companies have the resources to produce them all themselves. In addition, with increased diversification of customer segments and customer needs, shorter product life-cycles, and the need of companies to develop new technologies and provide products or services to the market more rapidly than before. Furthermore, as a result of the fact that the progression of ICT, such as the expansion of Internet, has enabled researchers throughout the world to easily access and share the information on advanced technologies, more useful technological ideas which may help create innovation are generated by various entities all around the world. This means that, today, a lot of useful ideas which may boost business exist outside the company, not only inside it (JPO, 2008a).

Against the backdrop of the growing technological complexity of products and processes, higher costs and risks of innovation, rapid change in customer needs, and the expansion of Internet - companies have started to change their innovation processes. Until now, the company was seen as a collection of countrybased subsidiaries, business units, or product lines. Now, however, companies view themselves as an array of specialised components: procurement, manufacturing, research, sales, distribution, and so on, and increasingly open up their innovation processes (Palmisano, 2006). They collaborate with external partners such as other companies, government research institutes and universities to acquire useful ideas and provide products or services more efficiently and rapidly to the market. They also sell or license their own ideas and technologies that are not being used to other companies to profit from them.

That is, companies embrace an "Open Innovation" strategy, where they actively utilise external useful ideas and technologies to provide products or services more efficiently and rapidly to the market, while allowing other companies to use ideas and technologies they do not themselves use (Chesbrough, 2003, 2006a; OECD, 2008). Companies such as IBM, Intel, and Procter \& Gamble all exemplify aspects of this open innovation model (Chesbrough et al., 2006). Today, innovation is not led by lone inventors in their garrets but is the product of a collaborative process that also combines technological and marketing expertise (Palmisano, 2006). Hence, employing an open innovation model as a part of the innovation process is increasingly important to enhance competitiveness and promote innovation (JPO, 2008a).

\subsection{Growing importance of patent transactions}

As companies begin to explore the way to make their innovation processes more open and the importance of circulation of knowledge grows, patents become a critical element of innovation. Some of the reasons why patents may play a critical role in fostering the exchange of ideas and technologies are as follows. 


\section{Freedom to operate}

From the perspective of a company that tries to bring in external ideas and technologies to its business, it must carefully examine whether it can use those ideas and technologies without infringing on the legal rights of other companies, since most external ideas and technologies which can be useful for its business are generally protected by patent rights. Especially in situations where the seller of the technology and the owners of the requisite patents differ, a company which wants to use that external technology in its business must negotiate not only with the seller of the technology but with all owners of requisite patents to acquire the legal ability to utilise that technology. Therefore, ensuring smooth patent transactions is essential to facilitate knowledge diffusion.

\section{Legal ability to control knowledge}

One key issue in a technology transaction is the information exchange necessary to evaluate the technology. The potential licensees or buyers need enough information on the technology to evaluate whether it is useful for their business or not. Technology suppliers must consciously limit the information they provide to prevent customers from acquiring enough knowledge about the suppliers' technology to develop it by themselves instead of licensing in or buying it from suppliers. As a result potential licensees or buyers must make evaluations and decisions based on incomplete information. This conflicting interest of both parties makes it more difficult to match suppliers and customers in the technology exchange transaction (Chesbrough et al., 2006). However, patents have a potential to solve this problem. By defining property rights and giving suppliers the legal ability to control their ideas and prohibit others from freeriding, patents make it easier for technology suppliers to provide enough information about their technology to potential buyers or licensees. Thus patents help to facilitate exchange of ideas and technologies between the many parties who possess useful knowledge.

Today, the nature and role of patents are changing. Facilitating the mobilisation, sharing, or exchange of patents becomes much more important to promote innovation in this globalised and well-networked world, where the circulation of ideas and technologies is essential to innovation. There is a view that patents are seen as the catalyst that enables knowledge to be shared (EPO, 2007). In this way, in the context of open innovation, intellectual property rights (IPRs) are increasingly expected to play a role as a means for transferring ideas and technologies from one entity to another, in addition to acting as a means for excluding others from using companies' own ideas and technologies (JPO, 2008a).

Consequently, the increasing need to facilitate the exploitation of patents puts a spotlight on the patent transaction market. The size and evolution of markets for patents are difficult to measure, because most patent transactions are conducted based on confidential agreements. Nevertheless, some available information suggests that markets for patents are growing.

International licensing, for example, appears to be on the rise. International receipts for intellectual property (including patents, copyrights, and trademarks) increased from USD 10 billion in 1985 to approximately USD 110 billion in 2004, with more than $90 \%$ of the receipts going to the three major OECD regions: the European Union, Japan and the United States (Figure 1). 
Figure 1. Receipts from international licensing in major OECD regions Billions USD

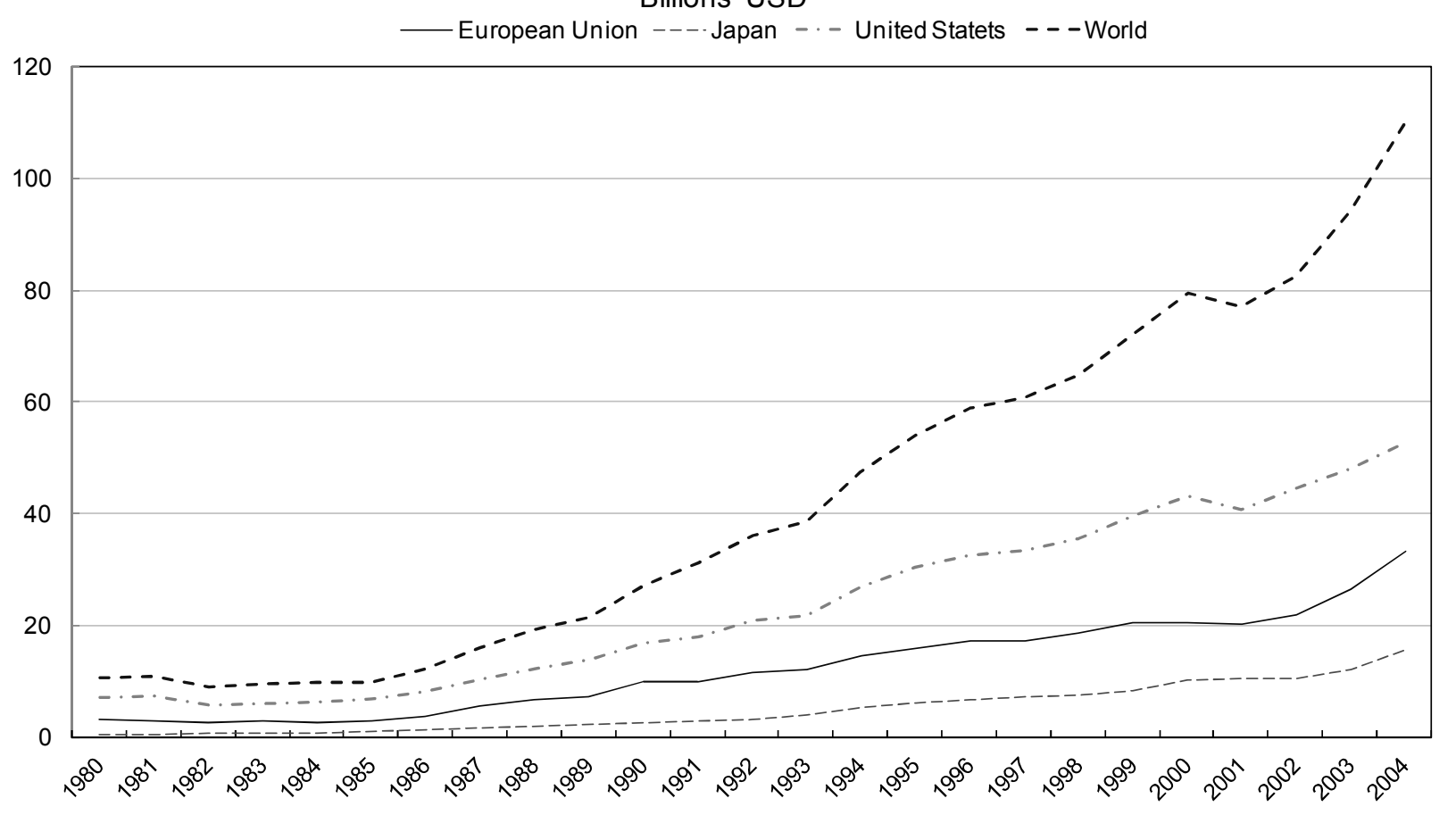

Source: OECD Science, Technology and Industry Outlook 2006.

This expanding marketplace can enhance the flow of patents by providing a channel through which companies can exchange or share their patents. The patent marketplace may become one of the key elements of innovation, since it facilitates the circulation of ideas and technologies through its ability to encourage patents to flow among a large number of companies.

Along with the development of the patent transaction market, a variety of new entities in the private sector that focus their own business on patent-related transactions have begun to emerge. These new players would also increasingly play an important role in promoting innovation.

Therefore, it would be important for governments to improve their understanding of such a marketplace and entities in order to support their development in the most socially beneficial directions (JPO, 2008a). This may also be important for traditional technology-oriented companies, since the effective use of patent transaction markets will help them improve their innovation processes and strengthen their competitiveness.

\subsection{Status of patent transaction marketplace}

In recent years, the market for intellectual property (IP) has experienced significant changes (e.g. a series of United States courts' decisions on patent remedies (damage awards, injunction) and licensing practices which have the potential to drive down the value of IPR, shift of companies' IP management from a defensive strategy to a more aggressive strategy, and the development of government policies aiming at fostering technology transfer among various entities such as companies, universities and public research organisations). However, some of the most significant recent changes in markets for IP have occurred through the emergence of new players whose business models are focused on extracting value from IP. Some IP specialist firms seek to monetise patents by creating strategic patent portfolios and licensing them. Others provide websites to establish online marketplaces where patents and ideas can be traded. And still others establish a co-operative venture that buys and licenses patents to its members for 
defensive purposes. They also include IP investment banks that will lend against the value of IP, and firms that seek to create funds, similar to mutual funds, which allow investors to earn revenue from royalties (FTC, 2008; JPO, 2008a). There may be other IP businesses that use intellectual property as their primary asset than those mentioned above.

Those entities now provide information, access, and even financing to enable transactions to occur, and could significantly influence the circulation of patents. Therefore analysing and understanding how these new players are performing in the patent transaction markets would be important both for traditional companies to utilise those IP businesses as a tool to improve the efficiency and speed of their innovation activities, and for governments to support the development and expansion of such businesses in a direction that is best for promoting innovation throughout the entire society. Analysis on these new players is therefore the central topic of this research.

\section{NEW PLAYERS AND ACTIVITIES IN THE PATENT TRANSACTION MARKET}

Markets for IP are developing fast: new types of IP transactions and new ways of developing and sourcing IP are emerging, which are in turn creating new business models. These arrangements are driven primarily by actors within the private sector. This chapter outlines the functions and business models of IP specialist firms (Table 1) and their current status.

As noted above, investigating business models of such IP specialist firms is important in order to grasp the current situation and problems of the patent marketplace. Due to the lack of comprehensive data about IP specialist firms that focus their business on generating revenue from patent-related transactions, the information in this report is based on various sources, e.g. website information, associations' directories, and information from key informants and patent transaction professionals. In a field like IP where relationships among businesses are important and the number of key players is relatively limited, information about people in the same business is well diffused among key players. Therefore, through interviews with some key players and Internet searches, the information about IP specialist firms in this report covers many of the primary players in the patent transaction market. The following table outlines business models and activities of specialist companies focusing on IP transactions. 
Table 1. Functions and business models of IP specialist firms

\begin{tabular}{|c|c|c|}
\hline Function & Business model & Specialist companies \\
\hline $\begin{array}{l}\text { IP management } \\
\text { support }\end{array}$ & $\begin{array}{l}\text { - IP strategy advice } \\
\text { - Patent evaluation } \\
\text { - Portfolio analysis } \\
\text { - Licensing strategy advice } \\
\text { - Patent infringement analysis etc. }\end{array}$ & $\begin{array}{l}\text { ipCapital Group; Consor; Perception partners; First } \\
\text { Principals Inc.; Anaqua; IP strategy group; IP } \\
\text { investments group; IPVALUE; IP Bewertungs; } \\
\text { Analytic Capital; Blueprint Ventures; Inflexion Point; } \\
\text { PCT Capital; Pluritas; } 1790 \text { Analytics; Intellectual } \\
\text { Assets; IP Checkups; TAEUS; The IP exchange } \\
\text { house; Chipworks; ThinkFire; Patent Solutions; } \\
\text { Lambert \& Lambert; etc. }\end{array}$ \\
\hline \multirow[t]{4}{*}{ IP trading mechanism } & Patent licence/transfer brokerage & $\begin{array}{l}\text { Fairfield Resources; Fluid Innovation General } \\
\text { Patent; ipCapital Group; IPVALUE; TPL; Iceberg; } \\
\text { Inflexion Point; IPotential; Ocean Tomo; PCT } \\
\text { Capital; Pluritas; Semi. Insights; ThinkFire; Tynax; } \\
\text { Patent Solutions; Global Technology Transfer } \\
\text { Group; Lambert \& Lambert; TAEUS; etc. }\end{array}$ \\
\hline & Online IP marketplace & $\begin{array}{l}\text { InnoCentive; NineSigma; Novience; Open-IP.org; } \\
\text { Tynax; Yet2.com; UTEK; YourEncore; Activelinks; } \\
\text { TAEUS; Techquisition LLC; Flintbox; First } \\
\text { Principals Inc.; MVS Solutions; Patents.com; } \\
\text { SparkIP; Concepts community; Mayo clinic } \\
\text { technology; Idea trade network; Innovation } \\
\text { Exchange; etc. }\end{array}$ \\
\hline & $\begin{array}{l}\text { - IP live auction/Online IP auction } \\
\text { - IP licence-right trading market }\end{array}$ & $\begin{array}{l}\text { Ocean Tomo (Live auction, Patent Bid/Ask); } \\
\text { FreePatentAuction.com; IPAuctions.com; TIPA; } \\
\text { Intellectual Property Exchange International; etc. }\end{array}$ \\
\hline & University technology transfer & $\begin{array}{l}\text { Flintbox; Stanford Office of Technology Licensing; } \\
\text { MIT Technology Licensing Office; Caltech Office of } \\
\text { Technology Transfer; etc. }\end{array}$ \\
\hline
\end{tabular}




\begin{tabular}{|c|c|c|}
\hline \multirow[t]{3}{*}{$\begin{array}{l}\text { IP portfolio building } \\
\text { and licensing }\end{array}$} & Patent pool administration & $\begin{array}{l}\text { MPEG LA; Via Licensing Corporation; SISVEL; the } \\
\text { Open Patent Alliance; 3G Licensing; ULDAGE; etc. }\end{array}$ \\
\hline & $\begin{array}{l}\text { IP/Technology development and } \\
\text { licensing }\end{array}$ & $\begin{array}{l}\text { Qualcomm; Rambus; InterDigital; MOSAID; } \\
\text { AmberWave; Tessera; Walker Digital; InterTrust; } \\
\text { Wi-LAN; ARM; Intellectual Ventures; Acacia } \\
\text { Research; NTP; Patriot Scientific RAKL TLC; TPL } \\
\text { Group; etc. }\end{array}$ \\
\hline & IP aggregation and licensing & $\begin{array}{l}\text { Intellectual Ventures; Acacia Technologies; } \\
\text { Fergason Patent Prop.; Lemelson Foundation; } \\
\text { Rembrandt IP Mgmt.; etc. }\end{array}$ \\
\hline $\begin{array}{l}\text { Defensive patent } \\
\text { aggregation/ } \\
\text { Framework for patent } \\
\text { sharing }\end{array}$ & $\begin{array}{l}\text { - Defensive patent aggregation funds } \\
\text { and alliances } \\
\text { - Initiative for free sharing of pledged } \\
\text { patents }\end{array}$ & $\begin{array}{l}\text { Open Invention Network; Allied Security Trust; } \\
\text { RPX; Eco-Patent Commons Project; Patent } \\
\text { Commons Project for open source software; etc. }\end{array}$ \\
\hline IP-based financing & $\begin{array}{l}\text { - IP-backed lending } \\
\text { - Innovation investment fund } \\
\text { - IP-structured finance } \\
\text { - Investment in IP-intensive } \\
\text { companies etc. }\end{array}$ & $\begin{array}{l}\text { IPEG Consultancy BV; Innovation Network } \\
\text { Corporation of Japan; Intellectual Ventures; Royalty } \\
\text { Pharma; DRI Capital; Cowen Healthcare Royalty } \\
\text { Partners; Paul Capital Partners; alseT IP; Patent } \\
\text { Finance Consulting; Analytic Capital; Blueprint } \\
\text { Ventures; Inflexion Point; IgniteIP; New Venture } \\
\text { Partners; Coller IP Capital; Altitude Capital; IP } \\
\text { Finance; Rembrandt IP Mgmt.; NW Patent } \\
\text { Funding; Oasis Legal Finance; etc. }\end{array}$ \\
\hline
\end{tabular}

\subsection{Traditional IP management support}

Corporate managers view patent as a powerful asset class, therefore the importance of developing strong patent management strategies grows. Under such circumstances, many IP-centric firms have begun to provide various services that support and enhance patent owner's IP management. Some firms analyse clients' patent portfolios, estimate the value of the patent portfolios and give the client advice on, for example, where the client firm is short on patents, what patents the client's competitors hold, and where the client can acquire patents that fill in the gaps. Other firms provide analytic software tools that allow users such as patent owners, patent lawyers, investors and other players to obtain various information about a single patent or patent portfolios; data on patent families, prior art and related patents, estimated market value of targeted patent or patent portfolios, and information on technology trends in a certain market that could be acquired through patent mapping. Still others help patent owners build and implement strategic patent licensing programmes by providing services such as detailed patent analysis, infringement analysis, potential licensee identification, licensing negotiation support and IP litigation support. 
IP management support firms provide various services ranging from patent portfolio development advice, patent evaluation, and patent licensing strategy formulation, to patent infringement analysis. Below is a selection of some services in this category.

\section{Services of IP management support firms (IP portfolio development support, licence support, infringement analysis etc.)}

Today, formulating a strong IP management strategy and taking full advantage of IP, especially patents, is essential for companies to strengthen their competitiveness in the market. Most patent owners, however, have not fully exploited their patent portfolios due to lack of strategic IP management, difficulty of evaluating true market value of patents, and the difficulty of identifying the potential markets for patented technology and complexity surrounding individual patent licensing issues. Under such circumstances, IP specialist firms such as ipCapital Group, Perception Partners, ThinkFire, TEAUS, CONSOR, Patent solutions, Anaqua, IP Strategy Group, IP Investments Group, IPVALUE Management and Chipworks (Box 1) are trying to help their client companies enhance IP management strategy and maximise the value generated from their patent portfolios by providing various services including patent portfolio development advice, IP valuation and strategic licensing programme formulation support. ThinkFire, for example, has provided IP advisory and transaction services to over 80 global technology companies and investment firms including Blachstone Group, Ciena, Hewlett-Packard, Kodak, NEC, Nokia, and Silver Lake Partners.

During the stage of patent portfolio development, these firms conduct detailed patent portfolio analysis and IP-based market analysis using their proprietary analytic tool or rating system. Some IP consulting firms create and utilise patent mapping when they analyse clients' patent portfolios and related markets. Patent mapping allows patent owners to easily understand what might be necessary for strengthening their patent portfolios by illustrating where the client company is short on patents, what patents the client's competitors hold, who is a potential licensee and from whom the client might be able to acquire key patents. Patent mapping also allows technology developing companies to develop new technology efficiently by indicating which technologies are already protected by others and which technologies are not developed yet. Patent mapping is significantly important for practicing companies, since entering new technology markets or expanding existing product lines across international borders requires a careful review of the global patent landscape. Based on information acquired through such analysis on clients' patent portfolios and related markets, IP specialist firms identify areas where their clients can generate revenue by utilising patent assets more strategically, or areas where their clients are vulnerable to patent assertion risk. Then, they provide their clients with guidance on the filing of additional patents, on patent acquisition, or on divestiture of some portions of portfolios so that their clients can enhance their patent portfolios and manage their IP asset more strategically.

Additionally, IP specialist firms also assist their clients to formulate and implement strategic patent in/out licensing programmes. Today, licensing patented technology is a significant revenue stream for many technology developing companies. Many technology companies, however, do not have enough human resources, capital and know-how to formulate and facilitate proper patent licensing programmes. IP specialist firms help these companies by providing licensing support services. When they support outlicensing, they mainly attempt to assist clients in finding potential licensees and closing licence agreements with those parties. In this transaction, IP specialist firms first conduct patent portfolio analysis and market research as discussed above. If they find that client's patent portfolios have some value, and identify potential licensees, then IP specialist firms help the client gain revenue from its patent assets, especially from under-utilised parts of the patent portfolios. They assist the client in negotiating the terms and conditions of the licence agreement with potential licensees. These firms sometimes represent their clients and negotiate directly with potential licensees as a licensing agent. In contrast, when these IP specialist firms work with a client wishing to obtain licences to use patents owned by other parties, they evaluate 
targeted patents, develop an in-licensing strategy and assist the client to close license agreements with holders of targeted patents.

Furthermore, when working with a client against whom another patent holder has asserted its patents, these firms support the client to establish a strong defense strategy by providing a variety of services including opponent party's patent portfolio analysis, patent infringement analysis (Box 1), settlement negotiation support, and IP litigation support.

\section{Box 1. Chipworks}

When patent owners wish to sell or license patents no longer required as part of their business strategy, or when patent owners recognised that their competitor's product might include their patented technology, they sometimes try to investigate whether there might be any infringement of the patents rather than simply selling or licensing them without any value indication.

When someone assert patents against some practicing companies, those practicing companies will also try to investigate the possibility of infringement before starting a settlement negotiation with the patent owner.

For such patent owners willing to sell/license patents, or for practicing parties whose goods are suspected of infringing other parties' patents, some firms such as Chipworks and TAEUS provide a patent infringement analysis service.

Chipworks, headquartered in Ottawa, Canada, was founded in 1992. Chipworks is a technical services company that analyses the circuitry and physical composition of semiconductors and electronic systems. Chipworks' patent infringement analysis service includes: market research across different companies and product lines; identification of potential infringing products; implementation of reverse engineering; and preparation for documents stating technical evidence to demonstrate whether or not the products infringe patents (Thumm, 2008). One of the most unique aspects of Chipworks' business is its reverse engineering process. Chipworks has over 70 circuit, process, and systems engineers. And in this transaction, Chipworks' reverse engineering experts take an existing product and disassemble it in order to understand how it was built, how it works and what it is made of. Then, based on the findings acquired through reverse engineering, Chipworks conducts a detailed analysis and produces claim charts to demonstrate whether the product in question does or does not infringe patents. Thus reverse engineering is used to support companies' IP and business strategy. To date, Chipworks has reviewed over 30000 patents and analyzed over 10000 products.

This service will allow patent owners to prohibit competitors from free riding their patented technologies by providing them with technical evidence to prove that other parties' technologies infringe their patents. For example, if a patent owner gets technical evidence which indicates potential buyer's/licensee's products use its patented technology by utilising an infringement analysis service, that owner can enhance its position in the negotiation and command a higher price, or can exclude competitors from using its patented technology easily. Patent infringement analysis may also help practicing entities who are being accused of patent infringement by other patent holders to determine whether its product infringes other parties' patents or not.

Thus, by utilising IP specialist firm's services efficiently, companies can develop strategic patent portfolios which strengthen their market position, gain revenue by launching strategic patent licensing programmes, or enhance protection of their business activities against third parties' patent assertions.

\subsection{IP trading mechanism}

Acquiring/in-licensing useful technologies from outside, and integrating such technologies into their core technologies is critical for companies to develop innovative technologies efficiently and enhance their competitiveness. In such circumstances, many companies begin to consider acquiring patents that cover key technologies in order to take ownership of such valuable technologies and develop more innovative technologies by utilising them without interference. Meanwhile, some companies wish to acquire patents from outside to reduce the risk of patent assertion against them by strengthening patent portfolios which can act as a defensive shield to protect freedom to operate. Furthermore, there are entities who are seeking patents not for producing and selling goods, but just for building a strategic patent portfolio and generating revenue by licensing it to many companies that might utilise the technology covered by that patent 
portfolio. For the many reasons mentioned above, entities are increasingly seeking opportunities for acquiring patents in recent years.

At the same time, companies increasingly attempt to divest or out-license some parts of their patent portfolios, especially under-utilised parts of the portfolios, since company managers begin to view their IP as important assets and recognise the importance of maximising monetary value generated from their IP. For instance, when a company has chosen to exit a particular business, it may decide to capture the monetary value of the related patents through their sale to another party for whom the patents are core to business.

Thus, companies increasingly seek to divest or acquire patents strategically to strengthen their business. However, so far most potential patent sellers and buyers have not been able to sell or buy patents efficiently. In many cases, patent holders do not have the resources, skills, or relationships with interested buyers which are needed for a successful patent sale. Moreover, most of them have difficulty in identifying the value of their patents, since the value of a patent is based on a number of factors including the breadth of the claims, how widely the patent is already being used or will be used in the future, and the ability to enforce the patent. Similarly, most willing patent buyers do not have enough resources and know-how needed to: identify the key patents and their proper market prices; launch and facilitate the negotiations with owners of target patents appropriately; and conclude contracts successfully.

For such companies, IP specialist firms are providing various services which will support and facilitate a patent transaction, and improve the mobilisation of patents. Following are outlines of some representative business models that may contribute to promote the smooth distribution of patents.

\section{IP broker}

Some IP-centric firms such as IPotential, Inflexion Point, Thinkfire, Pluritas, ActiveLinks, and Global Technology Transfer Group are offering IP brokerage service. These entities provide technical, legal and business expertise to connect willing sellers and prospective buyers of patents and complete patent transactions. Operations provided by IP brokers are almost the same as the patent licensing support service provided by IP management support firms as discussed above. So generally, it seems that the entities offering IP licensing support services are also providing IP brokerage services.

IP brokers operate on both the buy side and the sell side of patent transactions. On the sell side engagement, IP brokers help their clients raise cash through the divestiture of some or all of their patent portfolios. Basically, IP brokers first evaluate their clients' patents to understand their potential value. After determining that the patents have some value, they seek to identify potential buyers who have the possibility to acquire those patents, based on their network of informants in various industries, their connections within the IP brokerage community, and their broad knowledge of IP marketplaces. In collaboration with clients, they develop a price target and sales strategy. IP brokers then contact potential buyers, and facilitate negotiations with them. Finally, IP brokers negotiate a purchase agreement with the best prospective buyer and attempt to close the transaction successfully. When they support clients to enter into licence agreements, they attempt to close licensing deals with as many licensees as they can.

On the buy side engagement, IP brokers assist their clients to acquire valuable patents that relate to the technologies clients are interested in. In this engagement, IP brokers start by identifying acquisitioncandidate patents covering key technologies which are important for their clients' businesses. Then they approach owners of target patents and establish discussions regarding a potential patent acquisition or a licence for those patents, while preserving the anonymity of clients. By utilising IP brokers' buy side services, companies can not only expand opportunities to acquire external valuable technologies which 
enhance their technology development, but also solidify their patent portfolios and thereby minimise the likelihood that an infringement claim will be made.

As an example, IPotential has completed 123 transactions including transferring more than 3800 patents/patent applications since its inception in 2003. According to IPotential, the total transaction value is more than USD 265 million (IPotential, 2009). The role of IP brokers is increasingly important for diffusion of knowledge and technology, since they can facilitate transactions over IP, by helping to match supply and demand.

\section{Online platform for matching IP}

As discussed above, companies begin to consider acquiring useful external knowledge and technologies more actively, while attempting to generate revenue from letting others use internal knowledge and technologies they don't use. Many companies, however, are struggling with identifying who has available innovative technologies or who is the prospective buyer of internal technologies they wish to divest. Under such circumstances, companies such as InnoCentive (Box 2), Yet2, Tynax, UTEK, NineSigma, YourEncore, Innovation Exchange, Activelinks, and SparkIP offer web-based platforms that connect IP owners wishing to sell their intellectual property and IP consumers seeking valuable ideas and technologies. Services these firms are providing can facilitate the circulation of knowledge and technologies.

\section{Box 2. InnoCentive}

InnoCentive is a global, online marketplace where organisations in need of innovation, such as companies, academic institutions, public sector, and non-profit organisations, can utilise a global network of over 180000 problem solvers. InnoCentive began as a start-up incubated through the e.Lilly division of Eli Lilly in 1998, and spun off as an independent company in 2001.

InnoCentive provides an Internet-based platform designed to help connect those who have difficult research problems with those who have creative solutions to those problems. Companies, which InnoCentive calls "seekers", post their scientific challenges that remain unsolved inside their R\&D laboratories on the firm's website. Seekers include commercial, government and non-profit organisations such as Procter \& Gamble, Dow Chemicals, Avery Dennison, Pendulum, Eli Lilly and Company, Janssen, Solvay, GlobalGiving and The Rockefeller Foundation. "Solvers", who number more than 180000 , compete to win cash "prizes" offered by the seekers. Solvers can search for challenges posted by Seekers based on their interests and expertise. If a Solver comes up with a solution for a certain challenge, the solver will then submit a proposed solution to be evaluated by the Seeker. If the solution is selected as "best" by the Seeker, the Solver receives a pre-specified financial award ranging up to USD 1000000 from the Seeker, and the intellectual property rights associated with the solution are transferred exclusively to the Seeker. InnoCentive manages the entire transaction process, and identities of Seeker and Solver are kept completely confidential.

Around 900 challenges have been posted so far by some 150 firms. More than 400 have been solved. InnoCentive reckons the approach can work for innovations in different fields, from chemistry to business processes and even economic development (The Economist, 2009).

The survey which analysed InnoCentive's open innovation marketplace indicates that disclosure of problem information to a large group of outside solvers is an effective means of solving scientific problems. It also indicates that the further the focal problem was from the solvers' field of expertise, the more likely they were to solve it (Lakhani, 2007).

Below are overviews of some of the scientific challenges that have been solved through InnoCentive's open innovation marketplace. 


\section{Oil industry outsider solves oil spill recovery challenge}

The Ocean Spill Recovery Institute posted a problem in 2007 regarding the challenge of separating frozen oil from water on oil recovery barges. The successful Solver of this problem was a nanotechnology expert with no background in the oil industry. He used a tool from the cement industry that was originally designed to vibrate the cement to keep it in liquid form during massive cement pours (Hagel and Brown, 2009).

\section{TB alliance works to eradicate one of the world's deadliest diseases}

In late 2007, the TB Alliance, a product development partnership dedicated to accelerating the discovery and development of new and improved drugs to treat tuberculosis (TB), posted a Challenge on the InnoCentive website. The Challenge was seeking a solution to simplify the manufacturing process of a current drug compound. This new methodology would improve the efficiency and cost-effectiveness of producing the compound, making it more widely available and more effective against the spread of TB, which is responsible for one death every 20 seconds. Once the challenge was posted on the InnoCentive website, 344 InnoCentive Solvers signed a user agreement to gain details. Of these, 27 submitted proposals, which were reviewed by the TB Alliance. TB Alliance chose two winning proposals. One came from a scientist in China, and the other from a research fellow in Germany. Under the InnoCentive Challenge agreement, intellectual property related to the solutions goes to the TB Alliance, and each winner receives USD 20000. TB Alliance is now in the process of implementing the solutions. If the solutions prove to be successful in practice, their contribution to develop a cost-effective process will benefit millions suffering from TB (TB Alliance, 2008).

\section{IP live auction/Online IP auction, IP licence-right trading market}

Establishing a shared understanding of reasonable market prices for patent transfer or licence by reference to information on past similar transactions will be of significant importance to facilitate patentrelated transactions. Currently, however, it is very difficult for buyers and sellers of patents to get comparative data to make good decisions on whether they are paying the right amount for what they are buying, or whether their asking price is appropriate, since most transactions related to patent transfer or licensing have traditionally been conducted confidentially. In such circumstances, some IP specialist firms have begun to offer IP transaction services which may enhance transparency and predictability of the IPR market. Such IP transaction services include IP Auction and IP licence-right trading market.

An IP specialist firm named Ocean Tomo holds live auctions (Box 3) for patents with the purpose of creating a highly transparent marketplace which facilitates the exchange of patents.

There are also entities that provide online patent auctioning services. Such entities include Ocean Tomo (Box 4), IP Auctions and Free Patent Auction. These online auction dealers provide web platforms that allow willing patent sellers to list their innovative ideas protected by patents which are available for sale or license, and allow willing buyers to check if valuable patents are marketed.

Furthermore, a new approach aimed at improving the transparency and predictability of IPR markets as well as facilitating IPR transactions is emerging. Intellectual Property Exchange International is planning to provide a highly transparent IP licence-right trading market called "Unit License Right contract market" (Box 5).

These engagements may also promote the mobilisation of patents. In addition, these services may provide a price discovery function by allowing all market participants to monitor deal prices of individual patent transactions which have been confidential. 
DSTI/DOC(2009)9

\section{Box 3. Ocean Tomo's live IP auction}

In 2006, Ocean Tomo, headquartered in Chicago and established in 2003, conducted the world's first live auction for intellectual property in San Francisco. Ocean Tomo's live auction for IP was created with the intent of improving transparency in IP transaction markets - where almost all transactions have traditionally been conducted confidentially and potential sellers and buyers have not been able to access the information regarding past similar IP transactions and facilitating the open and public exchange of IP. Willing sellers may be able to broadly market their patents by utilising the live auction for IP provided by Ocean Tomo. Meanwhile, Ocean Tomo allows potential buyers to access information on patents which will be put up for a coming auction in advance. Such information includes names of the seller, bibliographic data of patents on sale, expected price, summary of the patented technology and potential target markets. By providing a lot of information about auctioned patents, Ocean Tomo assists willing buyers to develop an acquisition strategy and make decisions about whether they should buy, or how much they can spend on the target patents.

By the end of 2008, Ocean Tomo had held eight auctions across the United States and Europe. So far more than 267 transactions have been completed through this service. The results of all completed transactions, including transaction prices and transferred patent numbers, can be seen through its website. The total amount of money spent in transactions which took place through Ocean Tomo's live auction has reached approximately USD 112 million.

\section{Box 4. Ocean Tomo's Patent/Bid-Ask}

Ocean Tomo provides a service named Patent/Bid-Ask (P/B-A) for improving transparency in the patent transaction market and furthering IP liquidity. This programme provides an online marketplace that allows potential buyers and sellers to make and receive offers on patents. P/B-A allows patent owners who are willing to sell or license their patents to place their offers on the P/B-A website. The information posted on the website by willing sellers or licensors includes expected prices of their patents, issued numbers, patent family information. If there is a party interested in purchasing or obtaining an exclusive licence to posted patents, that party can place a bid on those patents anonymously, and the owner of those patents would receive a notification from P/B-A. Ocean Tomo also provides brokerage service as a part of its P/B-A programme to help patent owners and Bidders close gaps between posted Bids and Asks. Thus, by utilising P/B-A, both potential seller and potential purchaser could smoothly enter into and develop their negotiation concerning IP transactions. Potential purchasers and licensees could also anonymously place a bid even on patents that are not posted on the P/B-A website. Once a bid on an un-posted patent is placed on P/B-A, P/B-A brokers would contact the owner of that patent to see if the patent could be sold or exclusively licensed to other party. This means P/B-A enables potential purchasers or licensees to explore the possibility of acquiring every outside patent they want under anonymity, while it gives sellers the opportunity to broadly market their patents.

In addition to providing a platform through which potential buyers, sellers, licensors and licensees can make patentrelated transactions effectively, P/B-A has a potential for functioning as a place for price discovery for patent transactions. All offers to buy, offers to sell, offers to exclusive licence and final transaction prices are placed on the P/B-A website publicly and can be viewed by everyone visiting the website. Every party who is involved in a patent transaction and has difficulty finding a price for its patent could visit the P/B-A website, and draw upon the patent transaction price data it provides in determining its transaction price. 
DSTI/DOC(2009)9

\section{Box 5. Intellectual Property Exchange International (IPXI)}

\section{Unit license right contracts market}

IPXI, founded in 2007 by Ocean Tomo and headquartered in Chicago, is planning to provide the Unit License Right (ULR) programme in late 2009 with the aim of making a more transparent and efficient market for IP licensing by standardising IP licensing contracts, creating a level playing field for buyers and sellers, facilitating secondary market transactions in IP licences, and introducing a transformative model of IP enforcement (IPXI, 2009). The ULR programme consists of "Initial sales of ULR contracts" through which IPXI sells a certain number of consumable nonexclusive rights regarding certain patents (ULR contracts) to the willing licensees and a "Secondary market for ULR contracts" through which IPXI allows ULR contract holders to resell their extra ULR contracts at the market price. The ULR programme is outlined below.

\section{IP transfer from original IP owner to IPXI}

In the ULR programme, IPXI first forms one or more special purpose limited liability companies (SPC) with the aim of collecting patent portfolios from other patent owners. The SPC has no operations other than managing the initial sale of ULR contracts, auditing holders of ULR contracts, and engaging in enforcement actions on behalf of the IP owner, if necessary, against third-parties who infringe the patent rights. When collecting patent portfolios, the SPC carefully estimates the value of each candidate patent portfolio owned by a patent owner who wishes to liquidate his patents from various perspectives such as stability of the patents as legal rights, scope of claimed inventions, technology fields the patent portfolio covers and possibility of generating licensing revenue. After conducting required due diligence investigations regarding the patent portfolio, the SPC and the owner of the candidate patent portfolio will advance the negation to finalise marketing plans and licensee targets, and enter into either an assignment of patent agreement, or an exclusive patent licence agreement whereby the patent owner will assign or exclusively license a specified patent portfolio to the SPC (IPXI, 2009). In the latter case, the SPC will be authorised to issue the determined number of nonexclusive sub-licences to the patent portfolio (ULR contracts) and to enforce patents included in the portfolio against alleged infringers on behalf of the IP owner. Each candidate patent portfolio should contain at least one issued US patent and cover products currently, or soon to be, offered on the market, with substantial expected demand for licences. The agreement between the SPC and the patent owner will also include certain terms of the issuance of the ULR contracts, such as offering price and the number of ULR contracts to be offered (IPXI, 2009).

\section{Initial sale of ULR contracts}

Following the transfer or exclusive licensing of patent rights to the SPC, the SPC will manage an initial sale of a disclosed supply of ULR contracts. In an initial sale, the SPC arranges for the offer, sale and issuance of ULR contracts in one or more tranches (see the image below). 


\section{A brief description of a ULR issue}

A UIR issur will include: the IP :o bo liconsod; any applicab o rest rictions (geographical, field of use, etc.); definition of rights conferred by one ULR; total volume on offer; tranche pricing, etc.

\section{CORE DESCRIPTION OF ILLUSTRATIVE ULR TRADE}

ULR(s): U137A, B \& C Valve Seat Insert

PATENT: X,XXX,137 and continuations, continuations-in-part and foreign counterparts.

LICENSED FIELD OF USE: All

RESTRICTIONS: All secondary sales through IPX

ISSUER RIGHT TO USE: YeS

UNIT BASIS: One ULR covers one automotive or light truck engine

TOTAL OFFERED QUANTITY: 5 million license units offered in 50 unit lots

OFFERING TERM: 3 years

TERM OF LICENSE: Until consumed

\section{TRANCHES}

U137A: 1 million ULR's at an initial offering price of $\$ 0.50$ per unit (e.g. unit 1)

U137B: 1 million ULR's at an initial offering price of $\$ 0.75$ per unit (e.g. unit 1,000,001)

U137C: 3 million ULR's at an initial offering price of $\$ 1$ per unit (e.g. unit 2,000,001)

Source: Malackowski, 2009.

A certain percentage of proceeds generated from the initial sale of the ULR contracts will be paid to the original IP owner. The ULR contracts give the ULR buyer the right to use certain patents in prescribed products or services. So, by purchasing ULR contracts, the ULR buyer obtains a pre-paid licence to sell a prescribed number of units using the licensed patents. One key attribute of the ULR transaction is that ULR contracts are consumable. This means a ULR contract, a right to use a certain patent portfolio in a product or service, is consumed when the licensed process is practiced and the licensed product or service is offered for sale, or imported (Gray, 2008). Therefore, the number of units the ULR buyer can sell is equal to the number of contracts purchased (IPXI, 2009). To sum up, ULR contracts are a limited supply of rights to use specified IP in a product or service. For example, if a buyer expects to produce a total of 5 million products covered by patents included in a certain ULR, the buyer needs to purchase 5 million ULR contracts to produce those products as planned. Holders of ULR contracts have certain obligations, including the obligation of reporting to the SPC and IPXI on a periodic basis the number of ULR contracts consumed and the date on which such ULR contracts were consumed. Holders of ULR contracts also have to permit the SPC to perform an audit of usage of the ULR contracts. Consumption information is periodically released by IPXI to eligible market participants. The rates of consumption of the ULR contracts are important to prospective buyers, to the patent owner, and to any entity that may wish to speculate on future prices of the ULR contracts, since the consumption rates may affect the price of the ULR contracts in the secondary market for ULR contracts (Gray, 2008). 


\section{Initial Sale of ULR Contracts}

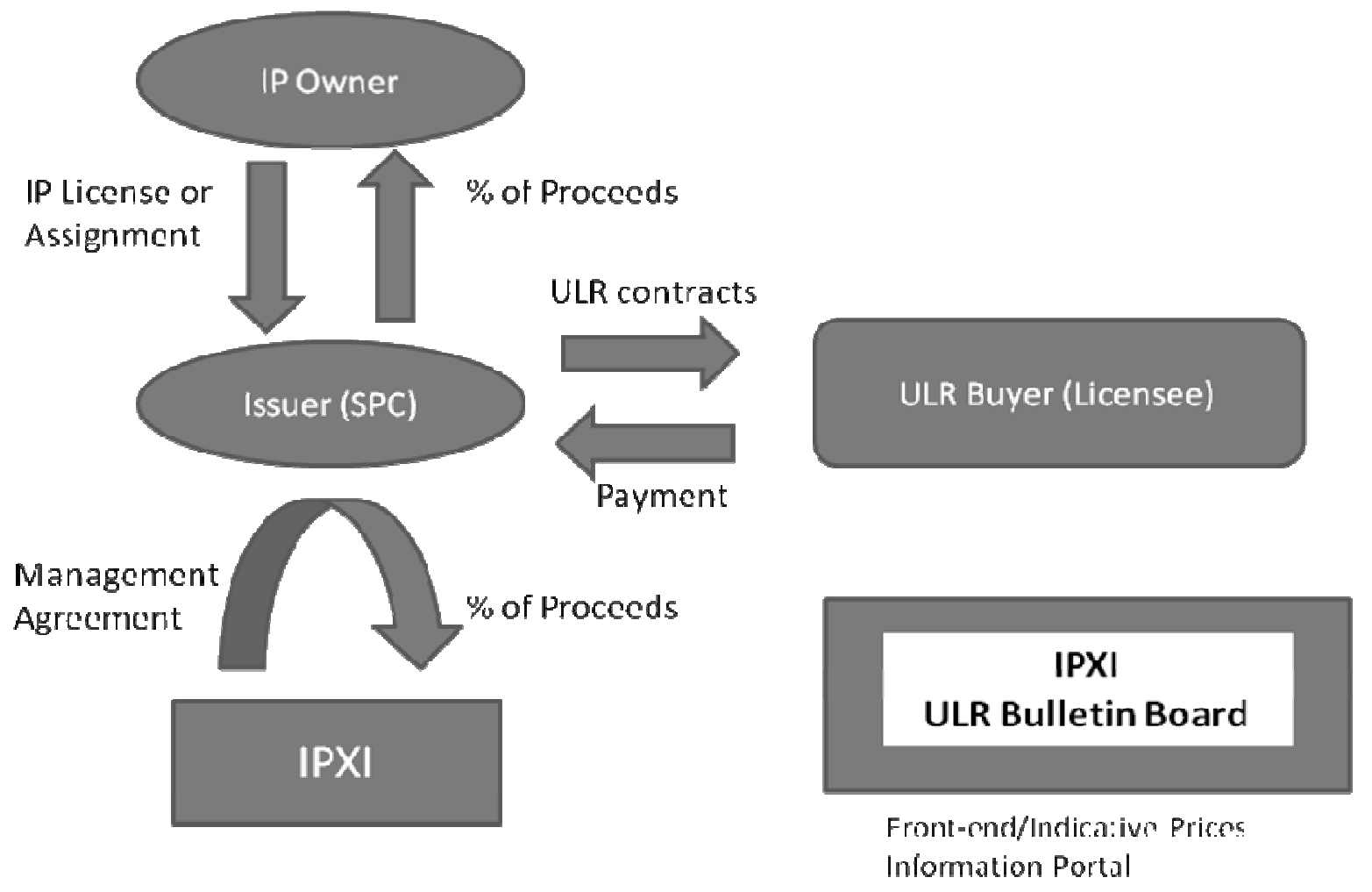

Source: IPXI, 2009.

\section{Secondary market for ULR contracts}

IPXI also facilitates a secondary market for ULR contracts. A secondary market for ULR contracts allows ULR holders who own excess inventory of ULR contracts and wish to liquidate such unconsumed ULR contracts to resell them. For example, if a company purchases 2.5 million ULR contracts at the initial sale, but later abandons the product line related to the purchased ULR contracts with an inventory of 1.0 million ULR contracts due to weaker-than-expected sales, the company can liquidate the rights at the market price by contacting IPXI and reselling such unconsumed ULR contracts through the secondary market for ULR contracts.

A secondary market for ULR contracts also allows willing buyers to purchase requisite ULR contracts. Therefore, the ULR buyers can strategically purchase ULR contracts at the initial sale or at the secondary market depending upon their business plans and ongoing demand for ULR contracts. For example, if a package of 25 million ULR contracts priced USD 2.00 per ULR comes to initial sale market and a buyer expects to consume a total of 2.5 million ULR contracts over the next 18 months, the buyer can choose to buy 1.25 million ULR contracts which will be enough to cover its needs over the next 9 months at the initial sale, based on the idea that it can purchase more at the market price later through the secondary market if sales of the product go as planned (Gray, 2008). By doing so, the buyer can avoid the risk of carrying a large excess inventory of ULR contracts when its business does not go well. On the other hand, however, the buyer will assume a price risk on the remaining 1.25 million, since the future price of the ULR contracts in the secondary market could be higher than expected. In practice, when considering a transaction through the secondary market for ULR contracts, the buyer will call IPXI and request an indicative price for a standard lot of ULR contracts and discuss whether its planned purchase is better accomplished in the resale market (the Secondary market for ULR contracts) or through participation in upcoming issuance of ULR contracts (the Initial sale of the ULR contracts) (IPXI, 2009).

Thus, the secondary market for ULR contracts may allow ULR purchasers to flexibly manage their demand for ULR contracts by providing the ability to resell extra ULR contracts or purchase additional ULR contracts without the cost and time of renegotiating a licence agreement. 


\section{Secondary Market for ULR Transaction}
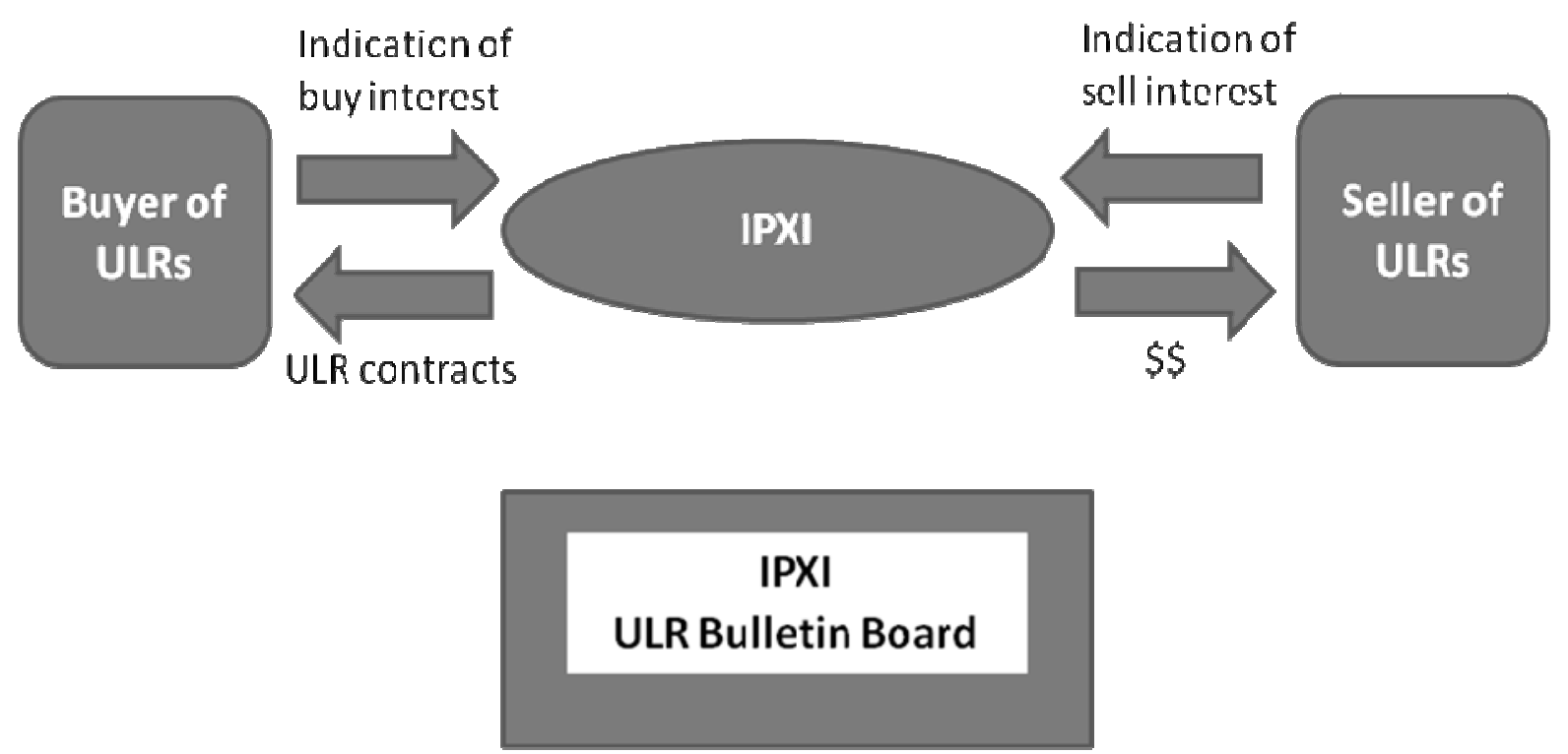

c.g.100,000 ULR202-A@US\$1.25

Source: IPXI, 2009.

The secondary market for ULR contracts may also provide a price discovery function by allowing all market participants to monitor prevailing licensing rates. The transparency and price discovery functions of an open secondary market will provide all buyers with a level playing field. The parties with access to such market pricing data that gauge market licensing levels will be able to monetise their IP more efficiently and strategically by using this information.

The ULR programme may have the potential to improve the efficiency and predictability of markets for IPR by offering a transparent and flexible framework for patent licensing and price discovery functions.

If a large number of patent transactions are conducted through arrangements such as IP live Auction, online IP auction or Patent/Bid-Ask, and thereby a large amount of information about patent transaction prices is accumulated, those who are willing to sell, buy or license their patents but have difficulty evaluating the value of their patents, might be able to find appropriate prices for their patents and facilitate their negotiation by referring to such information. Of course it would be difficult to identify the absolute value of patents directly from such information, since the value of a patent varies a great deal depending on the business environment surrounding that patent, such as who owns it, how it is managed and in which industry the owner mainly operates its business. For example, a buyer seeking protection for its own product line will estimate a different value than a buyer intent on launching a licensing programme across several firms (Monk, 2009). Even so, these kinds of arrangements have a possibility to enhance transparency in the markets for IP and help people involved in negotiations concerning patent transactions find reasonable market prices by providing much information about past patent transactions. Therefore development of these arrangements would be important for promoting innovation.

\section{Technology licensing/transfer office in universities and research institutions}

Transferring technologies created by universities and research institutes to the commercial market is important to promote innovation. Entities like university-TLOs have played a core role in facilitating technology and IP transfer/licensing from universities/research institutions to industry. For example, 
Stanford University Office of Technology Licensing (OTL) closed 107 new licence agreements, and received USD 62.5 million in royalty revenue from 546 technologies in fiscal year 2008 (OTL, 2008). While some IP specialist firms such as IP funds and IP aggregation/licensing firms recently began to put energy into acquiring university/research institutes technologies, the role of TLOs/TTOs as a platform to facilitate knowledge transfer from universities/research institutions to industry will become more important.

\subsection{IP portfolio building and licensing}

These are entities dedicated to developing strong patent portfolios by bundling complementary pieces of patents, and licensing them to others. Some firms build their patent portfolios based on the patents generated through their internal $R \& D$ activities. Others create patent portfolios through strategic acquisition of other parties' patents. These firms generally do not use their patents to provide any products or services. Instead, they attempt to establish licensing programmes based on their patent portfolios, and generate revenue from such licensing activities.

It is said that the emergence of these firms is changing the game of traditional patent management strategy, especially one particular strategy associated with litigation avoidance. Companies facing a patent assertion can use their patents as bargaining chips to avoid costly litigation, when the opponent party is also an operating company. This is based on the mutual deterrence effect; if two firms have patents aimed at each other's products, neither will seek to assert or litigate for fear that the other firm will do the same. However, when facing such an IP specialist firm which focuses solely on asserting its patents without providing any products and services, asserted companies cannot use their patents as bargaining chips. Thus, business models of IP specialist firms included in this category could significantly affect companies' IP strategies.

\section{Patent pool facilitator/administrator}

The importance of technology standardisation is growing. Especially in industries like telecommunications and computing where products are highly modularised and ensuring interoperability between components is critical, promoting technology standardisation is of significant importance to bring new products to market rapidly and efficiently (Shapiro, 2001; JPO, 2008a).

At the same time, setting a technology standard which does not include patented technology seems to be almost impossible, particularly in the fields related to advanced technology, since most useful technologies are protected by patents due to the growing importance of intellectual property in innovation activities. To make matters more complicated, in many cases essential patents required to provide a certain product or service are owned by a variety of different patent holders as a result of the development of horizontal division of labour related to $\mathrm{R} \& \mathrm{D}$ activities. This means those seeking to commercialise new products or services which include a certain standardised technology have to obtain licences from multiple patentees, which require significant cost, time and resources. In addition, if someone among the essential patent holders requires unreasonable royalties or refuses to license their patents to other parties, the diffusion of standardised technology may be discouraged.

Therefore, to promote standardisation of technology which is considered to be critical to innovation, particularly in areas like ICT, it is important to develop the environment that will enable potential licensees to easily access those patents essential for a certain technology. One possible solution lies in the formation of arrangements such as patent pools and patent consortiums. Patent pools or consortiums might have the potential to provide greater access to essential patents for practicing a certain standardised technology, as can be seen from the fact that these arrangements have been used by market participants to facilitate the licensing of patents related to certain technology standards. 
In general, a patent pool is an agreement between two or more patent owners to license one or more of their patents, which are generally essential for a certain technology, to one another or third party (Clark et al., 2000). It also could be defined as the aggregation of intellectual property rights which are licensed by patent owners to licensees through some medium, such as a joint venture set up specially to administer the patent pool (Clark et al., 2000; JPO, 2008a).

In the latter case, the patent pool is administered by an administrator, based on an agreement between the patent owners who own essential patents for a certain technology and the administrator. Patent owners transfer certain rights concerning their patents, which vary depending on the agreement, to the administrator. Generally the administrator will be authorised to issue non-exclusive sub-licences to the patents on behalf of patent owners. The administrator then attempts to generate revenue by broadly licensing those patents to other parties, and royalties from the patent pool will be distributed among the patent owners according to the pre-arranged distribution method. As such, a patent pool allows patent owners to gain an income from their patents without going through an individual licensing process which requires more time and resources. A patent pool can also provide an opportunity for patent owners to expand the market for their products by encouraging the spread of patented technology.

From the standpoint of companies which wish to use a technology covered by pooled patents in their businesses, a patent pool allows them to easily obtain most, if not all, of the licences required to practice the technology concurrently with a single transaction. In addition, by using a patent pool, licensees will be able to obtain the necessary licences cheaper than by obtaining them separately from each owner of essential patents, since patent pools generally have the function of controlling the stack of royalties for essential patents and provide package licensing at a reasonable price. A patent pool is considered to be one of the effective methods to enable potential licensees to access necessary patents efficiently, especially in industries such as telecommunications, computer hardware and software, where companies have to access dozens, or hundreds of patents to produce just one commercial product.

Thus patent pools may play a critical role in facilitating innovation, just as the patent pool regarding MPEG-2 is viewed as mitigating royalty stacking, promoting the dissemination of technology, and fostering innovation by reducing the potential for hold-ups (Gray, 2008).

Against the background mentioned above, IP specialists companies are now emerging that focus on facilitating and administering patent pools covering patents essential to certain technology standards. Firms such as MPEG LA, Via Licensing Corporation, SISVEL (Box 6), the Open Patent Alliance, 3G Licensing and ULDAGE are included in this type of business. 
SISVEL is a patent pool management company headquartered in Torino, Italy. It has branches in the United States, Germany, Japan and China. SISVEL was founded in 1982 by an agreement among some Italian Television manufacturers, in order to facilitate the utilisation of patents they owned. Its current business focuses on forming and administering patent pools which include essential patents for certain technologies, especially related to standard technologies. SISVEL is now administering several patent pools that contain essential patents for implementing i.a. MPEG Audio technology standards, DVB-T technology standards, and CDMA2000 technology standards. It also prepares for forming new licensing programmes with respect to DVB-H technology standards, etc.

As to the MPEG Audio technology standards, SISVEL has the exclusive worldwide right to license patents owned by six companies including Philips and France Telecom. Those patents cover essential elements of the ISO/IEC 11172-3 and ISO/IEC 13818-3 MPEG Audio Standards, the digital processing standards for compressing the audio signal and converting it in a digital signal. It licenses those patents to more than 1000 licensees including Apple, Microsoft, Nokia, and Toshiba.

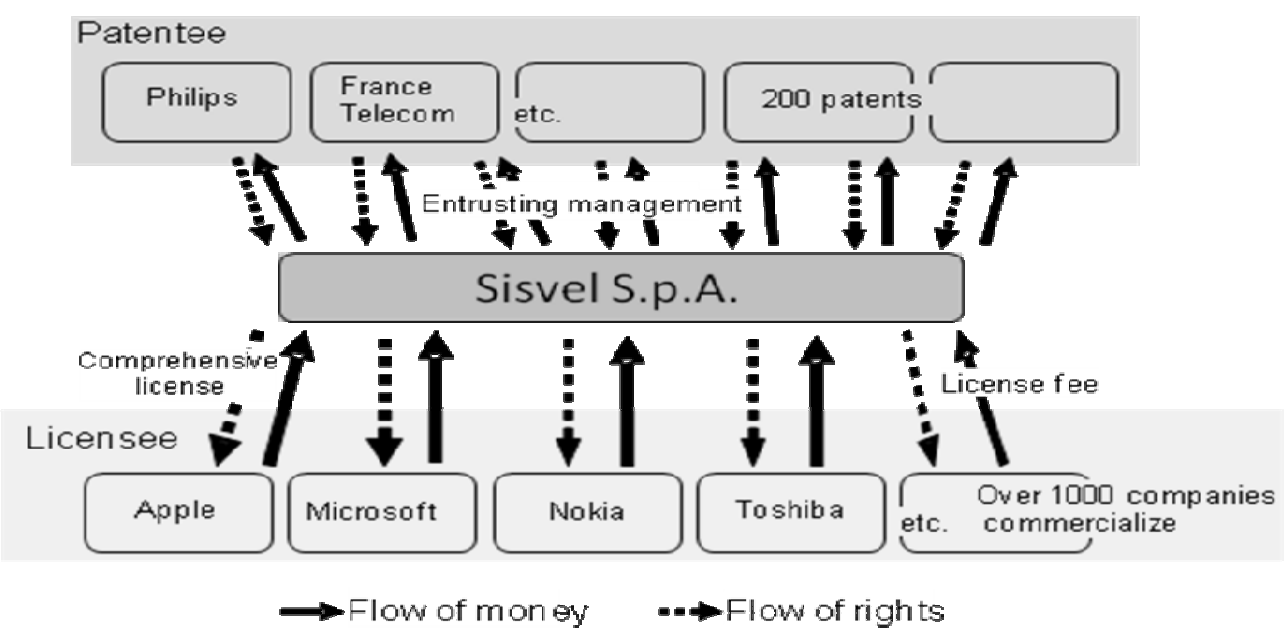

Source: JPO, 2008a.

SISVEL's business model is as follows. First SISVEL calls for essential patents for a certain technology standard. The interested parties with patents believed to be essential to the technology standard contact SISVEL and submit those patents for an evaluation of essentiality. SISVEL evaluates the essentiality of submitted patents by utilising an independent patent evaluator. Then SISVEL discusses with parties holding essential patents for the technology standard in order to decide the licensing terms, including licence fees and dividends of profit. After that SISVEL will get exclusive licences of those patents from the patent holders, and offer a joint licence of its patent portfolio to potential customers who hope to use patented technology covered by the portfolio in their business.

SISVEL's licensing programme enables licensees to acquire licences of patents necessary for a particular technology standard from multiple patent holders in a single transaction, instead of negotiating a licence with each of them.

There are arguments that patent pools have some anti-competitive effects. It is fact, however, that specialist firms focused on administering patent pools exist and are expanding the scope of their business.

\section{IP/technology development and licensing}

These are firms that spend a lot of money on R\&D activities like traditional technology-oriented operating companies with the aim of producing IP like patents or know-how and generating money from such IP. Some of these firms create products by using the technologies and patents they developed, as well as licensing such technologies and patents to others. However, most of them do not provide any products 
or services to the consumer. Instead, they focus on licensing their patents and know-how to many operating companies. Thus, many firms in this category make most or all of their money from IP, not from products. For example, Arm, a UK-based technology company achieving robust growth in revenues, controls a large chunk of the microprocessor patent market but manufactures very few products of its own, instead licensing its IP to other companies (Keeler, 2008). These firms often provide consulting services along with licensing IP to their licensees to integrate the technology into the licensees' products or processes (Millien and Laurie, 2007, 2008). Companies such as Qualcomm, Rambus, Intellectual Ventures, AmberWave, InterDigital, MOSAID, Tessera, Walker Digital and Wi-LAN are included in this category.

\section{IP aggregation and licensing}

These firms develop strategic patent portfolios basically through the purchase of other parties' patents that fit with their IP monetisation strategy. Then they launch patent licensing programmes based on their strong patent portfolios to generate money. Some of these IP aggregation firms raise money either from large technology companies or from capital markets to buy a number of valuable patents making up their portfolios (Millien and Laurie, 2007, 2008). They acquire money by licensing their patent portfolios to others, and then return some of the gains to their investors. Intellectual Ventures (Box 7), Rembrandt IP Management and Acacia Technologies are examples of such firms.

\section{Box 7. Intellectual Ventures}

Intellectual Ventures, headquartered in Bellevue, Washington, United States, was founded in 2000. Intellectual Ventures has branches in Japan, China, India, South Korea and Singapore, and now employs more than 550 staff worldwide. Intellectual Ventures is managing huge funds which are raised to invest in intellectual property. It is said that Intellectual Ventures raised around USD 5 billion from its investors (Sandhu, 2009; Page, 2009). Its investors are of two main types: the fund's financial investors, and the strategic company investors. Financial investors are much like any other private equity investors, receiving equity stakes in the underlying portfolio of assets in exchange for their funding. And the strategic company investors are licensees of a certain part of Intellectual Ventures' patent portfolio, as well as equity stakeholders in the assets (Page, 2009). It is said that such strategic investors include big companies such as Microsoft, Sony, Nokia, Intel, Google, eBay, and SAP.

The business model of Intellectual Ventures includes developing huge and strategic patent portfolios by using its considerable funds and licensing them to a number of companies which need to use those patents. Intellectual Ventures develops its patent portfolios not only through its own R\&D activities, collaborative research with universities and research institutes, but through acquisition from other parties. So, simply stated, the business model of Intellectual Ventures includes both features of an IP/Technology development and licensing firm and an IP aggregation and licensing firm.

The USD 5 billion that Intellectual Ventures has raised is divided between three funds. The oldest fund, Invention Science Fund I, is mainly a seed capital fund, investing in building inventions from scratch. The second fund, Invention Development Fund I, is focused on extending its IP creation and monetisation ecosystem globally, especially via its tech-transfer partnering programme in Asia. The third and largest fund, collectively Invention Investment Fund I \& II, is focused on investing in existing inventions acquired in large part from individual inventors and SMEs (Page, 2009).

Making a carefully-crafted patent investment strategy is critical for Intellectual Ventures to develop a number of strong patent portfolios. One key process used to create strategic patent investment plans for strong patent portfolios is its brainstorming meetings called "Invention Session", typically held a few times per month, where world-class experts in a diverse range of science and technology areas meet and discuss possible solutions to problems in various technological areas. Based on the discussion in Invention Sessions and other information obtained from various analyses, Intellectual Ventures creates technology development road maps which identify what kind of technologies will be needed or what kind of technologies should be developed in the future. Then, based on such technology development road maps Intellectual Ventures creates its patent investment strategies in various technology areas (Chesbrough, 2006a, 2006b). After creating a strategic investment plan, Intellectual Ventures attempts to acquire valuable patents to develop strong patent portfolios by investing in various resources including its own R\&D activities, research projects in universities or research institutes and existing inventions. Intellectual Ventures indicates it has so far spent over USD 135 million on its own invention creation activities, USD 315 million acquiring assets from individual inventors and about USD 848 million with SMEs, enabling these businesses to commercialise their inventions (Page, 2009). 
As mentioned, Intellectual Ventures invests part of its huge funds in its own R\&D activities with a goal of creating new promising inventions and subsequently developing strategic patent portfolios. Some inventions are created directly from its Invention Sessions. After each session, a team of in-house patent lawyers reviews the discussion to look for promising ideas. Then it examines the market potential of chosen ideas, and covers them with patent applications (Chesbrough, 2006a, 2006b). Intellectual Ventures also creates patentable ideas through internal research projects conducted in its invention laboratory. The Intellectual Ventures Laboratory was officially launched in May 2009. The mission of the laboratory is to work on prototyping and conducting advanced research on its technology-oriented inventions. Inventors at the laboratory work on a variety of projects ranging from global health and biomedical devices to responses to energy and climate challenges (IV, 2009). As of July 2009, Intellectual Ventures is said to have about 55 senior inventors with expertise across diverse fields including computer science, electrical engineering, physics, and rocketry on its payroll. Fewer eight of them work for the company full time. About 25 are university professors, the rest are consultants, or retired. Intellectual ventures says it has been filing about 500 patents a year for the last few years, and it has already filed approximately 2000 patent applications that result from its own invention creation activities (Page, 2009).

Internal R\&D activities are not the only source by which Intellectual Ventures acquires patentable ideas. In addition to investing in internal R\&D activities, Intellectual Ventures also seeks external investment opportunities. Intellectual Ventures explores a wide range of technology areas including software, electronic devices, networking, biotechnology and medical devices, to find subjects of investment that own or might be able to generate promising ideas. One of Intellectual Ventures' strategies for acquiring external ideas is to partner with universities and research institutions to help them commercialise their IP. By investing in outside knowledge resources such as research projects in universities and research institutes that fit with its vision, Intellectual Ventures expects to acquire promising patentable inventions. In 2008, Intellectual Ventures opened offices in Singapore, Tokyo, Beijing, Seoul, and Bangalore in order to build and support inventor networks in Asia. Each of these offices has a staff of approximately 20 professionals, including technologists, market analysts and IP experts. As of July 2009, Intellectual Ventures works with about 160 universities worldwide, including about 100 outside the United States. One example is the memorandum of understanding (MOU) it signed with the Indian Institute of Technology-Bombay (IIT-B) in March 2009. This transaction aims at helping IIT-B, which currently holds about 130 patents, to monetise its IP more systematically. Intellectual Ventures will pay IIT-B a licensing fee for its patents, as well as bearing the ongoing maintenance costs of its patent portfolio. If Intellectual Ventures succeeds in negotiating licences, it will feed back a portion of the profits to the inventors. The partnership is non-exclusive. So IIT-B can engage with others on patent-related matters (Page, 2009). In Korea, it is reported that Intellectual Ventures has secured the right to become co-owner of about 260 patentable ideas from Korean universities such as Seoul National University and the Korea Advanced Institute of Science and Technology.

Intellectual Ventures also invests in existing patents. At this stage, it acts as an active collector of external patents to develop its patent portfolios. Intellectual Ventures attempt to purchase patents from various sources including big companies, universities, bankrupt companies and individual inventors. For example, it attends bankruptcy auctions of failed startup companies to buy their patents. Over the past few years, Intellectual Ventures is considered to have amassed over 27000 patents and patent applications related to various technology areas (Page, 2009). Intellectual Ventures generates revenues by utilising its patent portfolio strategically such as by licensing its patent portfolios to users and potential users of its patented technologies. Intellectual Ventures licenses its patents on a non-exclusive basis. A huge patent portfolio, created through patent creation and patent collection, enables Intellectual Ventures to provide various licensing packages in a variety of different technology areas. To maximise the value of each licensing package, patents included in the licensing package might be customised according to customer needs when it is licensed out. Until now, it seems that much of Intellectual Ventures' licensing programme has been with big companies. For example, it is said Intellectual Ventures has secured payments in the range of USD 200 million to USD 400 million from companies including Verizon Communications Inc. and Cisco Systems Inc. However, as Myhrvold told the Wall Street Journal, many of future deals may be with smaller companies, and for smaller amounts in the range of USD 5 million to USD 10 million. So far, through strategic licensing activities, Intellectual Ventures has already returned more than USD 1 billion in licensing fees to all investors (Page, 2009).

\subsection{Defensive patent aggregation/Framework for patent sharing}

Recently, IP specialist firms have emerged that seek to acquire patents just to assert them against alleged infringers. This behaviour by such IP specialist firms facilitates one particular IP strategy associated with litigation avoidance. Some practicing companies are trying to acquire potentially 
problematic patents that can be asserted before active IP enforcers acquire them, and get them off the street to avoid costly and damaging litigation (Monk, 2009).

Under such circumstances, IP-centric firms are emerging that seek to acquire patents selectively just for defensive reasons. Such entities include Open Invention Network (Box 8), RPX (Box 9) and Allied Security Trust. These IP-centric firms acquire patents that have potential to be asserted if an aggressive patent enforcer gets them, and license them free of charge to anyone willing to share the financial burden of acquisition of the patents.

In addition to the above-mentioned activities, new initiatives that intend to facilitate sharing and accessing of patents covering specific technologies by collecting patents and allowing anyone to use them free of charge are emerging in some technology fields. The Eco-Patent Commons (Box 10) in the green engineering field and the Patent Commons Project for open source software are primary examples of such initiatives. The Patent Commons Project provides online databases containing information on patents which companies agreed not to assert against the open source community under certain terms and conditions so that developers and users of open source software can utilise existing software without worrying about patent infringement issues. For example, IBM said it would not assert its patent portfolio against the Linux kernel in 2004. In 2005, IBM pledged open access to innovations covered by its 500 software patents to individuals and groups working on open source software. Nokia announced that it allows all its patents to be used in the further development of the Linux Kernel in 2005. In addition, in 2005 Sun Microsystems published a declaration of non-enforcement of its US and foreign patents against any implementation of the Open Document Format (ODF) for Office Applications (OpenDocument) v1.0 Specification or of any subsequent version of ODF.

\section{Box 8. Open Invention Network}

Open Invention Network is an IP specialist firm formed in 2005 with the aim to promote innovation in Linux, a free operating system developed under the GNU General Public License and the source code of which is freely available to everyone, by protecting the open source community from the threats of patent assertion and litigation from those who assert their patents against the Linux System. Open Invention Network has considerable industry backing. It has received investment from a diverse group of companies including IBM, NEC, Novell, Philips, Red Hat and Sony.

Open source software development has been one of the key sources of innovation. It has reduced costs and improved the functioning of softwares efficiently. In particular, the development of Linux has made a tremendous contribution to innovation in the software and hardware industry. Recently the idea has been transferred to all manner of projects ranging from an open source encyclopedia called Wikipedia and collaborative industrial design such as ThinkCycle, to open source aeroplane design. Even NASA has embraced the idea by using volunteer scientists (or "clickworkers") to identity and catalogue craters on the surface of Mars (Watson, 2008).

One of the keys to innovation in the Linux community might be the ability to share software codes and ideas. The Linux community spurs innovation because individual software developers and companies continue to work from, and build, a shared library of software code that is available to all. This model means developers can focus their energies on creating improvements to existing Linux code without having to develop the same base of software code from scratch. In fact, sharing the development workload among the Linux community creates higher-performance software, at a lower cost and with fewer quality issues. Therefore, encouraging open collaboration between developers is critical to the continuation of innovation in the Linux System. Impediments to collaboration and the sharing of ideas threaten to slow innovation in the Linux ecosystem.

In such circumstance, Open Invention Network is refining the intellectual property model so that important patents related to the Linux System are openly shared in a collaborative environment. Open Invention Network acquires patents related to all areas of software useful in protecting the Linux System, and makes them available royalty-free to any company, institution or individual that agrees not to assert its patents against the Linux System. This enables the Linux community, including Linux developers, distributors and users, to invest in and use Linux with less worry about intellectual property issues. As of march 2009, Open Invention Network has accumulated more than 275 patents and patent applications (OIN, 2009).

By developing a web of Linux developers, distributors, sellers, resellers and end-users that license its patent portfolio, Open Invention Network is creating a supportive and shielded ecosystem to ensure the growth and adoption of Linux. 


\section{Box 9. RPX}

San Francisco-based RPX, founded in 2008 , is a firm devoted solely to buying patents. It is backed by the venture capital firms Kleiner Perkins Caufield \& Byers and Charles River Ventures. The latter is also an investor in Intellectual Ventures, the above-mentioned IP specialist firm founded by former Microsoft executive Nathan Myhrvold (Klee, 2009). RPX's strategy is exactly the opposite of the other patent funds which acquire patents with the intent to build strong patent portfolios and license them. RPX buys patents with the expressed intention of not using them and not suing anyone else. What RPX is doing is to create a defensive patent pool which retires patents that could lead to expensive lawsuits from active patent enforcers.

RPX raises money from big companies by asking for an annual membership fee ranging from USD 30000 to USD 5 million, depending on the company's size. In return the members get rights to use every patent RPX has bought. So far 14 members including I.B.M., Cisco Systems, Panasonic, Philips, LG Electronics, Samsung, TiVo, Seiko-Epson and Sony have signed up for the service. Members of RPX do not have any vote in what the company buys. If member companies do not like the way RPX is running its portfolio, they can choose not to renew their membership. Even though they will still be able to keep the licences to the patents purchased while they were members. RPX is also using its initial financing from the venture capitalists to buy patents.

RPX purchases patents from various sources. For example, it purchased licences to a patent that relates to an encryption method used for digital discs from Acacia Research, one of the leading companies that buy patents for financial gain. This deal helped encourage Panasonic, Samsung, LG and Philips to join RPX, since Acacia had sued 18 electronics makers claiming the Blue-ray system infringes on this patent. While RPX itself will not file suits to exploit the value of what it buys, it may resell the patents to investors after it has licensed them to RPX members. In some cases, it has bought a limited number of licences to a certain patent, with the option to buy more, so it can make sure RPX members can use the technology while leaving the patent owner free to negotiate with or sue others. In this way, RPX can prevent non-member companies from free riding (Hansell, 2009).

RPX has bought more than USD 90 million worth of patents, concentrating on those that apply in broad areas like user-interface design or call-center management. RPX is looking for patents that can be asserted or are already being asserted. It buys target patents from small companies, individual inventors and brokers. It also buys patents at IP auctions (Klee, 2009). Deciding which patents to buy is among the biggest challenges of making this structure work. 


\section{Box 10. Eco-Patent Commons}

One of the interesting approaches for promoting smooth utilisation of patent rights is Eco-Patent Commons. In January 2008, four companies, namely IMB, Nokia, Pitney Bowes and Sony, in conjunction with the World Business Council for Sustainable Development (WBCSD), launched the Eco-Patent Commons with the aim to facilitate sharing and accessing of patents that pertain to technologies having environmental benefits. The Patent Commons is an effort to encourage the development of technologies that will help to protect the global environment by collecting environmentally beneficial patents and allowing anyone to use them free of charge (JPO, 2008a).

Patents included in the portfolios of the Patent Commons project are pledged by patent owners who hope to be a member of the project. Which patents should be submitted to the Commons is left to the discretion of each company. However, the patents submitted must show an environmental benefit. The lists of pledged patents are provided through a searchable web-based database maintained by the WBCSD.

All entities including non-member entities who have not pledged their patents to the Commons can easily access and utilise the inventions and solutions pooled in the Commons. As the open software community has shown, free sharing of knowledge could foster innovation by allowing new players to enter into the market and use the shared knowledge to improve technologies in related fields. Free sharing of knowledge will also provide a platform on which companies can establish new co-operation and collaboration to foster joint innovation.

To date, about 100 patents have been pledged by nine companies: IBM, Sony, Nokia, Pitney Bowes, Xerox, DuPont, Bosch, Ricoh and Taisei Corporation.

This could be one of the solutions to promote innovation in the area of environmental technologies, if many valuable patent portfolios are available through the Commons. The Commons has to create a much bigger and more valuable collection of patents to make this structure more efficient. The key issue for success is how it can give potential members who own eco-friendly patents incentives for pledging their patents to the Commons.

\subsection{IP-based financing}

These are companies that provide IP-based financial instruments such as IP-based collateral, IP-based investment and IP-securitisation. By assessing the value and risk of a counterparty's IP carefully, these companies provide capital to their counterparty against its IP. Below are typical business models IP specialist firms in this category are employing:

\section{IP-backed lending}

These are companies that provide financing for IP owners usually in the form of loans, where the loan is secured either wholly or partially by IP assets. These companies take into account a borrower's IP assets in structuring a financial transaction, instead of focusing on traditional assets like real estate, equity.

\section{Invention investment fund}

Entities are emerging which invest money raised from the capital market in promising inventions, especially in inventions related to future-oriented developing technologies. These entities invest money in a number of invention sources with cutting-edge technologies, such as universities, research institutes, individual inventors and small start-ups. In return, these entities acquire IPRs related to inventions they invested in with the aim of bundling complementary pieces of IPRs concerning certain technologies across the organisational boundaries and thereby developing strong patent portfolios. Then, they generate revenue by launching patent licensing programmes which offer joint access to the bundled patents. Innovation Network Corporation of Japan (Box 11) and Intellectual Ventures are examples of companies that employ this business model. 
DSTI/DOC(2009)9

\section{Box 11. Innovation Network Corporation of Japan}

The Innovation Network Corporation of Japan (INCJ), launched in July 2009, is an investment fund co-funded by the Japanese government and 16 private companies. The purpose of INCJ is to promote innovation and enhance the value of businesses in Japan by providing financial, technological and management support. The INCJ will invest in innovative businesses in areas like advanced materials, electronics, energy, environment, life sciences, and machinery (INCJ, 2009).

The fund has so far raised JPY 90.5 billion (about USD 960 million): JPY 82 billion (about USD 870 million) from the Japanese government and JPY 8.5 billion (about USD 90 million) from 16 companies (see list of corporate investors). The Japanese government will also provide up to JPY 800 billion (about USD 8.5 billion) in loan guarantees. So, INCJ has an investment capacity of around JPY 900 billion (about USD 9.6 billion).

Source: INCJ, 2009.

\begin{tabular}{|l|}
\hline List of corporate Investors \\
\hline Development Bank of Japan Inc. (DBJ) - Founding partner \\
\hline Shoko Chukin Bank Limited - Founding partner \\
\hline Asahi Kasei Corporation \\
\hline Osaka Gas Co., Ltd. \\
\hline Sharp Corporation \\
\hline Nippon Oil Corporation \\
\hline Sumitomo Chemical Co., Ltd. \\
\hline Sumitomo Corporation \\
\hline Sumitomo Electric Industries, Ltd. \\
\hline Takeda Pharmaceutical Company Limited \\
\hline Tokyo Electric Power Company, Inc. \\
\hline JGC Corporation \\
\hline Panasonic Corporation \\
\hline Hitachi, Ltd. \\
\hline The Bank of Tokyo-Mitsubishi UFJ, Ltd. \\
\hline General Electric Company, Japan \\
\hline
\end{tabular}

A portion of those funds will be used to acquire promising technologies and intellectual property assets owned by universities, institutions and companies. In this transaction, for example, INCJ will invest in entities like IP funds which develop and manage certain patent portfolios and encourage dissemination of technologies covered by those patent portfolios by broadly licensing them (see the image below).

Such IP funds may collect patents related to certain promising technologies from various resources including universities and research institutions in return for providing financial or, if necessary, IP strategy building support to them, and develop patent portfolios. Then the funds will generate revenues from those patent portfolios by licensing them to those who wish to use the patented technology for commercialisation or for further research. 


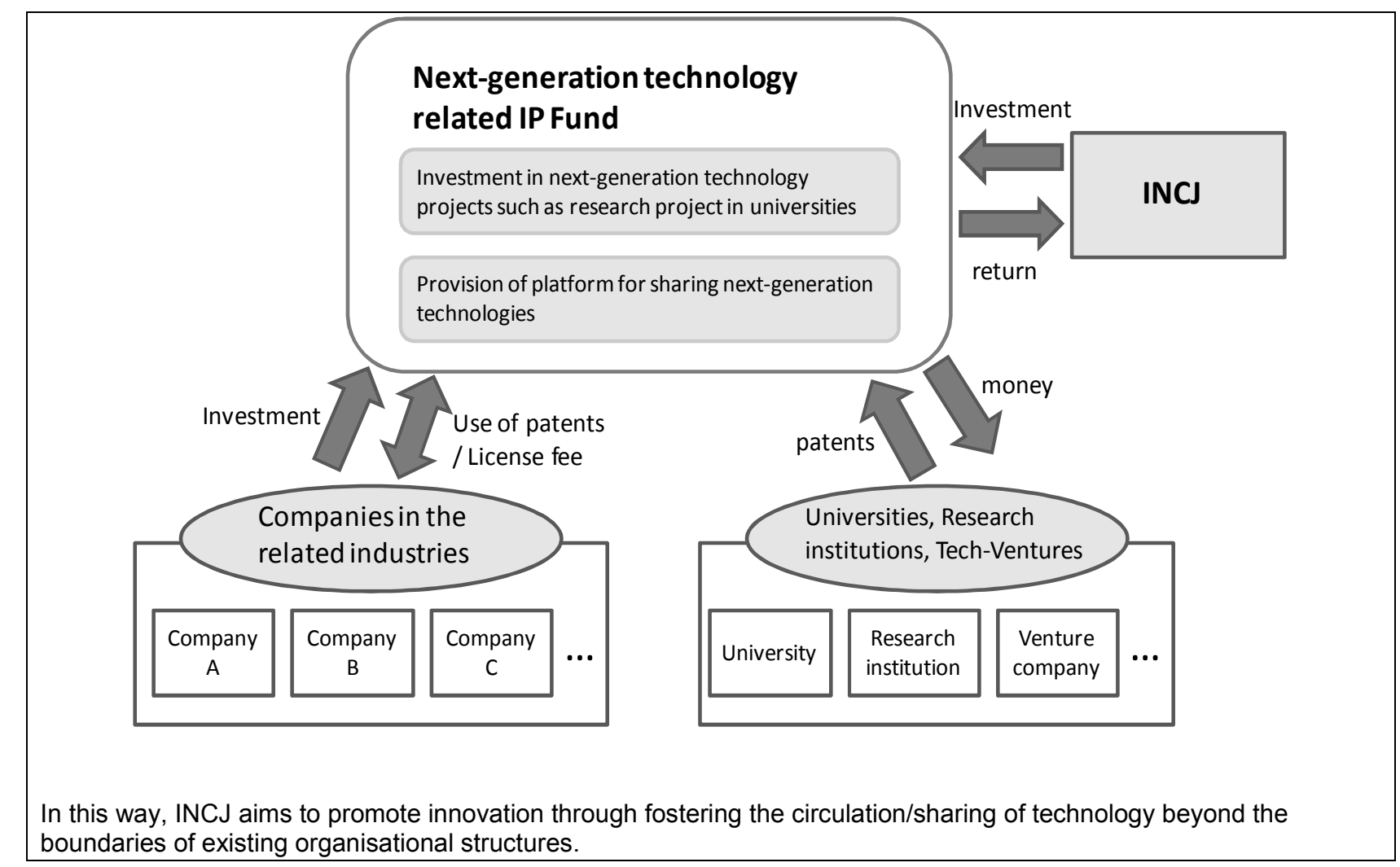

These businesses are still new. So it is too early to analyse the impact of this business model on innovation. However, this business model's fundamental concept of "creating innovative technologies and new businesses by combining the knowledge beyond the boundaries of existing organizational structures" may open the door for technologies and IP assets that have potential but remain dormant within the limited boundary of the current owner's business, to shine in the new open field. In addition, their function of collecting complementary pieces of IPRs and offering one-stop shopping for those IPRs can facilitate diffusion of knowledge/technology.

\section{IP-based structured finance}

Companies in this category provide financing capital to IP owners in return for acquiring their revenue-generating IP, such as patent rights and existing royalty interests. These companies allow IP owners with revenue-generating IP to seek the way to exchange future cash flows generated by IP for current cash by offering structured financing of IP.

So far, most IP-based structured finance agreements seem to have been concluded in the life science industry. This marketplace emerged in the early 1990s and is still dominated by a handful of royalty acquisition funds including Royalty Pharma (Box 12), DRI Capital, Cowen Healthcare Royalty Partners (Yurkerwich, 2008). For example, DRI Capital is an investment management company, focused on investing in royalty streams in the healthcare industry, managing over USD 1 billion. DRI Capital's Royalty Monetization Fund acquires existing royalty streams from companies, research institutions and inventors. It has acquired over USD 850 million in royalty-based cash flows on commercialised products (DRI Capital, 2008).

Outside the life science industry, structured sales of patent rights are less common. However, firms such as alseT IP and Patent Finance Consulting (Box 13) are providing IP-based structured finance services in various technology fields without focusing only on the life science field. 


\section{Box 12. Royalty Pharma}

Royalty Pharma, founded in 1996, acquires revenue-producing intellectual property - principally royalty interests in marketed and late-stage biopharmaceutical products. Royalty Pharma does not discover, develop, manufacture or market products. Instead, the Company provides capital to universities, research institutions, inventors and life science companies who own revenue-producing intellectual property in exchange for their royalty interests.

Since inception in 1996, the company has acquired various royalty streams, including its USD 700 million purchase of the Lyrica ${ }^{\circledR}$ royalty from Northwestern University, its USD 650 million purchase of the Remicade® royalty from New York University, its USD 700 million purchase of the Humira ${ }^{\circledR}$ royalty from AstraZeneca plc following its acquisition of Cambridge Antibody Technology, its joint USD 525 million acquisition with Gilead Sciences of Emory University's emtricitabine royalty interest and its acquisition of approximately $80 \%$ of Memorial Sloan Kettering's United States and international royalty interests in Neupogen $₫$ and Neulasta ${ }^{\circledR}$ for over USD 400 million.

Royalty Pharma currently owns a diversified portfolio of royalty interests in several biopharmaceutical products,

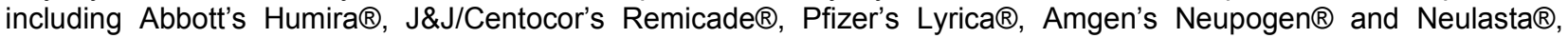

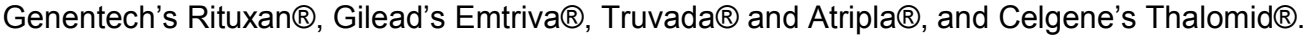

Due to increased royalty revenue from existing products and the acquisition of additional royalties, the total royalty revenue generated by Royalty Pharma's royalty-interests portfolios is rapidly growing each year.

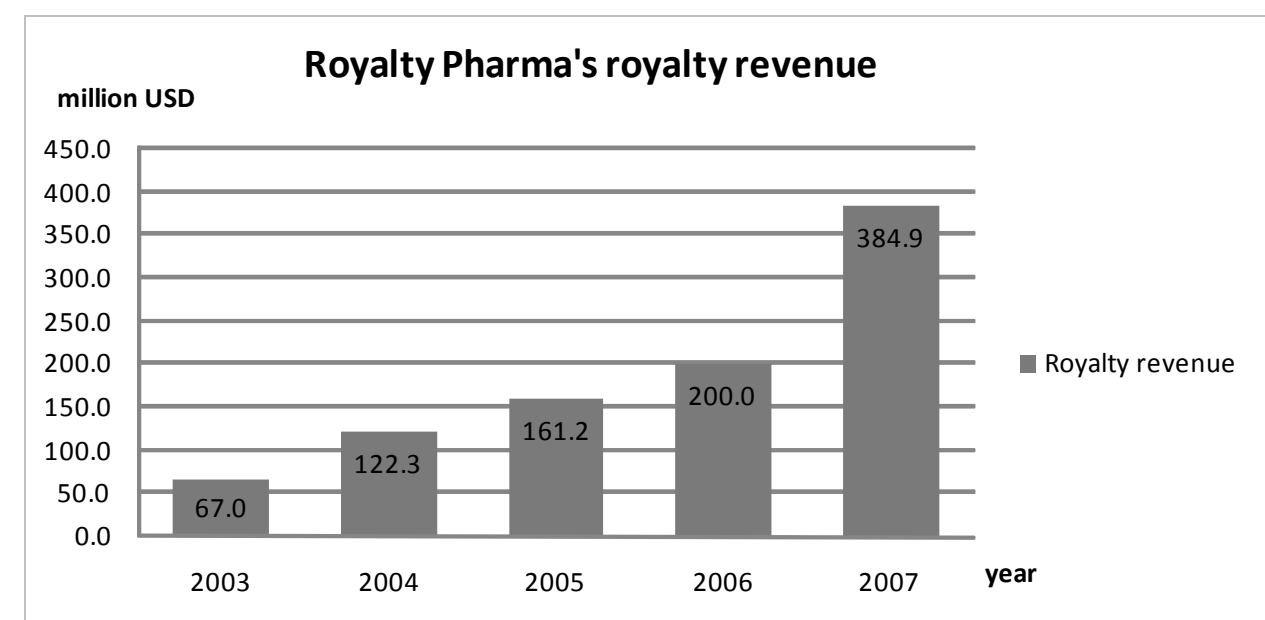

Source: Royalty Pharma, 2009a.

\section{Example of Royalty Pharma's transactions:}

In August 1984, Amgen Corporation and Memorial Sloan-Kettering Cancer Center (MSKCC) initiated an exploratory collaborative research programme. Participation in the programme guaranteed MSKCC the opportunity to negotiate a licence for the use of any inventions or technologies developed as a result of this collaboration. Eighteen months later, MSKCC and Amgen entered into a licence agreement for the use of patented technologies for the development of Neupogen $\AA$ and Neulasta $\AA$, creating a royalty interest for MSKCC on these products.

In January 2004, Royalty Pharma acquired a portion of MSKCC's US royalty interest in Neupogen® and Neulasta ${ }^{\circledR}$. The transaction involved an upfront cash payment, equity in Royalty Pharma, and additional payments by Royalty Pharma if yearly sales exceed certain specific amounts. This transaction enabled MSKCC to retain an interest in the product by selling only a portion of the royalty interest, while materially diversifying the institution's assets. 


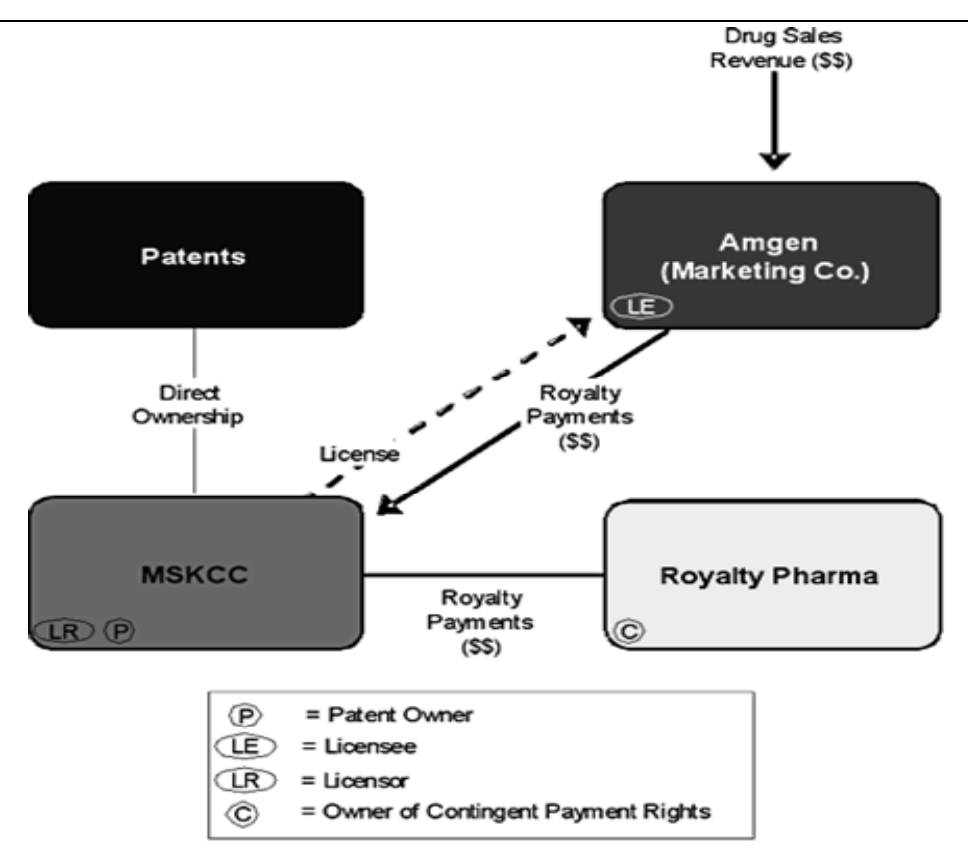

Source: Royalty Pharma, 2009b.

\section{Box 13. Patent Finance Consulting}

Patent Finance Consulting, based in Tokyo, provides IP structured finance programmes as one of its comprehensive IP services. Patent Finance Consulting manages a JPY 10 billion (about USD 11 million) fund called "Kyushu investment fund for the development of technology". Through this fund, Patent Finance Consulting invests money in firms owning competitive technologies and patents to help them commercialise their valuable technologies. In this transaction, the IP owner transfers its R\&D project and IP underlying the transaction to a Special Purpose Company (SPC), in order to isolate the transferred IP from the risk of the original IP owner's bankruptcy. Patent Finance Consulting then invests money raised by investors in the SPC in order to support the commercialisation of products developed through the project. To date, Patent Finance Consulting has invested in four projects through its IP structured finance programmes.

\section{Example of transactions: Robo-catcher developing business}

Patent Finance Consulting established a special purpose company (SPC) for commercialising the "Robo-catcher" developed by MechaTracks Co. Ltd. MechaTracks transferred its technical seeds and related IP such as patents, trademarks, development rights, and distributorship related to the Robo-catcher project to the SPC. Then the Kyushu investment fund for the development of technology, managed by Patent Finance Consulting, invested a total amount of JPY 100 million (about USD 1 million) in the SPC to encourage the commercialisation of products developed through the Robo-catcher project. MechaTracks and the Kyushu investment fund for the development of technology will accept the distribution from SPC. 


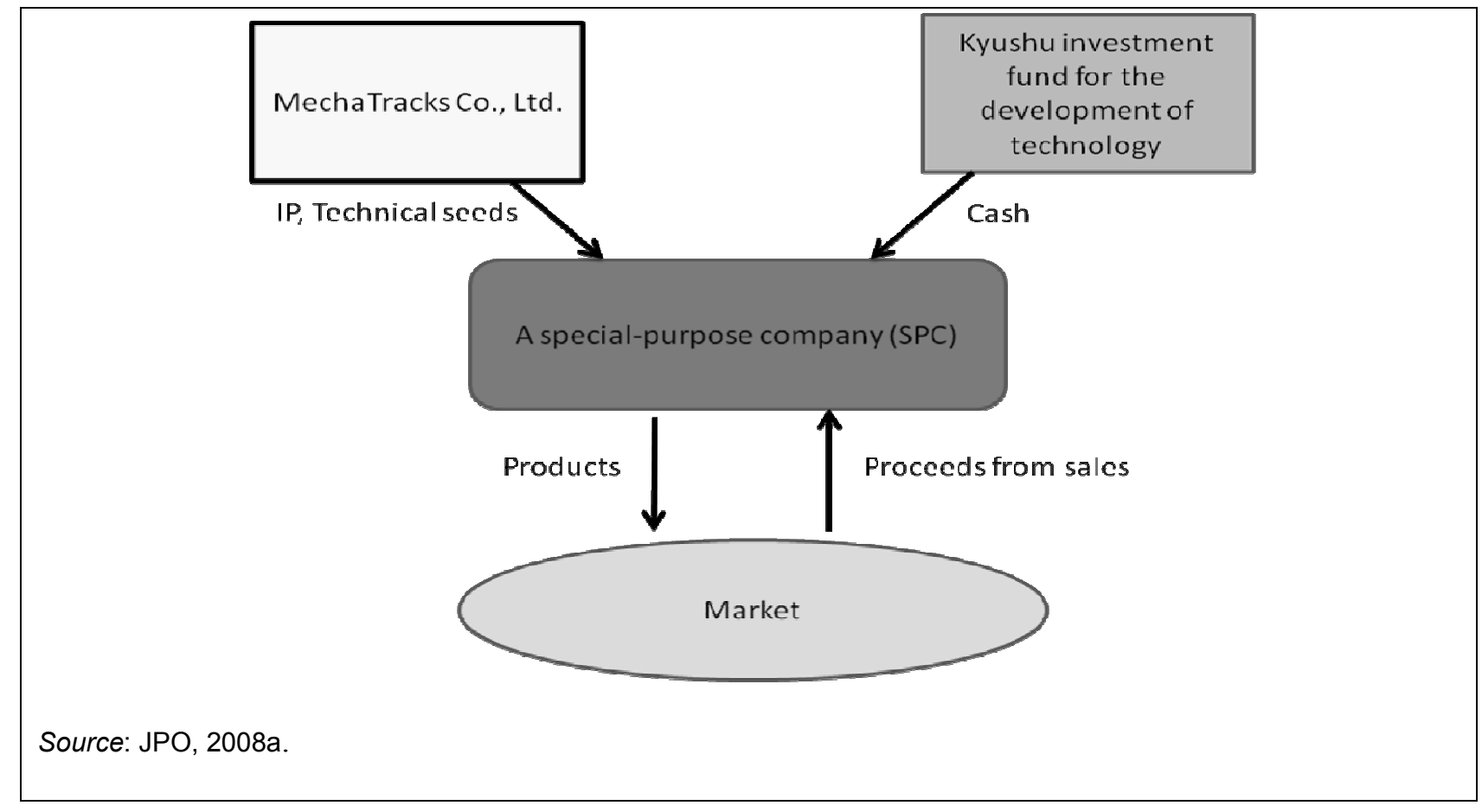

These IP specialist firms may help companies holding valuable IP that will generate revenue but will not match their near-term financial demands by providing IP-based financing solutions. IP owners can get an upfront payment in exchange for selling all or a portion of their IP, such as patents and future royalties, to such IP specialist firms. And then IP owners can use the proceeds to reinvest in their product lines, develop new products, or finance other strategic initiatives. Thus this IP-centric financing model has a potential to support innovative companies that own prospective IP, but do not have enough capital to invest in further R\&D activity to develop further technology.

\section{Investment in IP-intensive companies}

These are entities which raise money from investors and loan the money to companies that own valuable IPRs such as patents, trademarks and copyrights based on which the IP owners can assert IPR infringement against other parties or launch licensing programmes. The goal of these entities is to acquire a financial interest generated from borrower's IPR-exploitation activities such as patent infringement litigation and patent licensing. Usually these entities also provide IP consulting services so that their clients can manage their IPR more strategically and maximise the value extracted from their IPR portfolios. Firms such as Altitude Capital Partners (Box 14), NW Patent Funding, IgniteIP, Coller IP Capital are prime examples of this category. 
DSTI/DOC(2009)9

\section{Box 14. Altitude Capital Partners}

New York-based Altitude Capital Partners, founded in 2005, is a private equity fund manager focused on investing USD 250 million in companies which own strong intellectual property portfolios. Altitude's investors include numerous hedge funds and other institutional investors. Since the fund's inception in 2005, Altitude has finalised more than 16 transactions. The IP portfolios of companies in which Altitude has invested cover technologies in fields such as Internet commerce, high speed data communications, network security and semiconductor chip design.

One example of Altitude's transactions is its investment in Deep Nines, Dallas, a Texas-based network security solutions provider founded in 2000. In 2007, Altitude invested USD 8 million in Deep Nines. Deep Nines was then suing McAfee. Deep Nines technology consolidates several different types of network security functions into a single system to more effectively prevent malicious traffic from entering a computer network. The proceeds from the investment allow Deep Nines to enhance its sales, marketing, R\&D and patent monetisation activity. Meanwhile, under the terms of the arrangement, Altitude is not only entitled to acquire an equity interest in Deep Nines, but can also get some of the cash Deep Nines raises from its IP monetisation programmes such as IP licensing agreements and IP litigations (Altitude Capital Partners, 2007). In 2006, Deep Nines sued McAfee, alleging McAfee infringed on a Deep Nines' patent that deals with detection of attackers at firewalls (Seyfer, 2007). On 15 July, 2008, a jury in the Beaumont Division of the United States District Court for the Eastern District of Texas found that certain applications of McAfee's IntruShield infringe upon Deep Nines' patent, and awarded USD 18 million for past and future damages. On 29 July, 2008, Deep Nines and McAfee settled their patent litigation matters by entering into a USD 25 million settlement agreement. As part of the agreement, McAfee acquired certain non-exclusive rights, and they entered into a mutual release of all related claims (McAfee, 2009).

Another example of Altitude's investment is Visto, which makes mobile e-mail software. In 2007, Altitude invested USD 35 million in Visto 8\% convertible preferred stock with 5-year maturity (Barron, 2008). Visto had been suing several companies including Microsoft, Research In Motion (RIM) for infringing its patents related to synchronising information between servers and mobile devices (Vardi, 2007). Visto sued Microsoft in December 2005 in the United States District Court for the Eastern District of Texas for violating three patents for technology that automatically pushes e-mail from the Internet to wireless devices. Visto and Microsoft settled their patent dispute in 2008. The companies did not disclose details of the settlement. Visto, however, said in a press release that it has entered into a licensing deal with Microsoft that involves cash and non-cash considerations. In the case of RIM, Visto first sued RIM for patent infringement in 2006 in the United States federal court in the eastern district of Texas. In July 2009, RIM and Visto announced they have entered into an agreement to settle all patent disputes between the companies. According to a jointly issued press release, the key terms of the settlement involve: RIM receiving a perpetual and fully-paid licence on all Visto patents; a transfer of certain Visto intellectual property; a one-time payment by RIM of USD 267.5 million; and the parties executing full and final releases in respect of all outstanding worldwide litigation (RIM, 2009).

Most notably, Altitude also invested USD 6.25 million in MercExchange whose lawsuit against eBay led to a United States Supreme Court ruling on when it is proper to grant injunctions against infringers (Seyfer, 2007). In 2001, MercExchange sued eBay, alleging that eBay's online auction interface which allows users to purchase items without going through the bidding process infringed upon three of its patens. The case was sent back to the lower courts in Eastern Virginia by the Supreme Court in 2006. In 2007, the lower court ruled that eBay must pay about USD 30 million in damages to MercExchange as part of a dispute. In 2008, MercExchange and eBay announced they had agreed to a settlement. eBay said in a press release that it agreed, as part of the settlement, to purchase all three patents involved in the lawsuit, as well as some additional related technology and inventions and a licence to another search technology-related patent portfolio that was not asserted in the lawsuit (eBay, 2008).

These businesses could allow companies which wish to generate revenues from IP, but do not have the ability to manage IP enforcement programmes, to enforce their IP strategically by providing financial support and expertise to implement IP exploitation activities. However, there are arguments that activities of such IP-specialist firms may encourage unnecessary patent infringement disputes and deter the promotion of innovation. 


\section{ACTIVITIES OF PUBLIC ORGANISATIONS FOR FOSTERING IP MARKETS}

Governments and public organisations in many countries are also providing a number of programmes aimed at fostering the marketplaces for IP, in consideration of the importance of such marketplaces as a driving force for diffusion of technology and ideas. Such programmes are varied, ranging from convening workshops and seminars focusing on the exploitation of IP, to formulating guidelines for IP licensing and revising relevant legislation, and establishing databases of licensable patents (OECD, 2006).

Although it is difficult to identify the effectiveness of these programmes against development of IP markets quantitatively, these programmes may have made some contribution to improve the environment of markets for IP. For example, the patent licensing advisor programme provided by INPIT (Box 15), which is a public institution in Japan, is reported to have undertaken more than 12000 IP-related licensing transactions since it began in 1997. Thus, the public sector also plays a significant role for the development of IP markets. Below are some examples of such programmes:

\subsection{Provision of information about licensable inventions}

Public authorities have a role to play in ensuring disclosure of information regarding inventions that are available for licence in order to facilitate the diffusion of knowledge. Some government agencies and public institutions are developing and providing databases for licensable patents which allow anyone to easily access the information on licensable patents owned by various entities including SMEs, universities and research institutes, with the aim of facilitating patent licensing activities. For example, the European Commission created the Community Research and Development Information Service (CORDIS) which provides information about EU R\&D programmes and transferable technologies. In Germany, INSTI, which comprises 39 private and public regional institutions, runs the Internet-based service called Innovation Market to link buyers and sellers of technology (OECD, 2006). The German Patent and Trade Mark Office (DPMA) provides the information on licensable patents through its online database. The Intellectual Property Office in the United Kingdom (UKIPO) also provides an online database which contains the information about licensable patents. In Japan, the National Center for Industrial Property Information and Training (INPIT) provides an online database of licensable patents through which anyone can obtain free of charge the information on licensable patents such as the owner's identity, patent grant number and terms of licensing. As of August 2009, the database stores information on about 45500 licensable patents. In April 2009, INPIT also started to provide a new database with information on licensable patents related to research tools in life sciences.

\subsection{Matchmaking services}

Beyond providing information about licensable inventions, a number of governments have taken more active steps to facilitate the diffusion of knowledge. Some public institutions are providing matchmaking services between buyers and sellers of technology. The European Commission (EC), for example, established a network of Innovation Relay Centres (IRC Network) in 1995. Services include help in matching buyers and sellers of technology, including through the Internet-based system in collaboration with the CORDIS Technology Market Place, and provision of advice on innovation, intellectual property, licensing and negotiation (OECD, 2006). The IRC Network is now part of the Enterprise Europe Network, made up of nearly 600 partner organisations across 40 countries. The Enterprise Europe Network offers all the innovation and technological co-operation services provided by the former IRC Network. In the United States, the National Technology Transfer Center (NTTC), established by Congress in 1989, provides access to federally funded technology and market assessment services, technology marketing, IP management support, technology transfer training and assistance in finding strategic partners (OECD, 2006). To date, NTTC has delivered over 450 technology transfer training courses to nearly 7000 professionals. In Japan, the INPIT, in addition to providing a database of licensable patents, also offers 
matchmaking services that aim to link buyers and sellers of patented inventions. One such service is the patent licensing advisor dispatch programme. INPIT dispatches about 100 Patent Licensing Advisors, who are experts on intellectual property rights and technology transfers, all over Japan in order to support patent licensing activities of companies, universities and research institutes. More than 12000 IP transfer transactions have been concluded through this programme since it started in 1997 (JPO, 2008b).

\subsection{Development of licensing guidelines}

A patent on a basic invention with no substitutes may allow its holder to bar follow-on inventors who would be willing to invest in R\&D to create socially useful applications. Therefore, for instance, if a patentee who owns patents covering fundamental inventions essential for advancing follow-on research such as research tools in genomics and biotechnology areas does not allow others to access those patented technologies in reasonable conditions, innovation in such fields could be discouraged and public benefit could be harmed significantly. In response to this concern, some public authorities develop guidelines for patent licensing which focus on certain technology fields closely related to public interest for the purpose of advancing further research in such fields by facilitating the diffusion of patented technology. The OECD Council, for example, adopted in 2006 Guidelines for the Licensing of Genetic Inventions which outline principles and best practices for the licensing of genetic inventions used for purposes of human health care. The Guidelines are also applied to the licensing of intellectual property rights that relate to genetic inventions used for the purpose of human health care. In the United States, in 1999, the National Institutes of Health (NIH) issued guidelines in order to ensure the access to technologies invented by NIH funding research. In Japan, the Council for Science and Technology Policy also issued guidelines for the purpose of facilitating the use of research tool patents in the area of life science technology, in 2007. The NIH and INPIT also provide a database which discloses information on intellectual property rights relevant to research tools in life sciences owned by universities, research institutes and private companies. For example, the database developed by the INPIT contains information related to research tool patents such as identities of patent owners, issued number, terms and condition of licensing. Such actions can facilitate access to important patented innovations and their use, by promoting patent licensing activities.

\subsection{Clarification of regulations regarding patent licensing activities}

Clarifying public authorities' enforcement policy that can affect firm's IPR transactions will help to facilitate patent and technology diffusion just as MPEG-2's business review letter from the US Department of Justice became the standard which other prospective patent pools relied upon in developing their preferred pool. Therefore, to promote patent and technology licensing, governments have taken steps to clarify regulations that can affect firm's IP transaction activities. In the United States, for example, the Federal Trade Commission and the Department of Justice issued "Antitrust Guidelines for the Licensing of Intellectual Property" in 1995 and "Antitrust Enforcement and Intellectual Property Right: Promoting Innovation and Competition" in 2007, in order to disseminate agencies' competition views with respect to activities involving intellectual property and assist those who need to predict whether the competition agencies will challenge their conduct as anticompetitive. At the European Union level, a new technology transfer block exemption regulation, with a safe harbour rule governing patent licensing, know-how and software copyright, entered into force in May 2004 as part of a broader set of reforms to competition law that are expected to increase legal certainty (OECD, 2006). The Japan Fair Trade Commission issued "Guidelines on Standardization and Patent Arrangements" in 2005 to clarify competition policy issues related to patent pools affecting technology standards. The Japan Fair Trade Commission also issued "Guidelines for the Use of Intellectual Property under the Antimonopoly Act" in 2007 with the aim of facilitating IPR-related transactions by clarifying its enforcement policy. 
In recent years, some public authorities have used policy levers regarding remedies available in patent litigation, such as a permanent injunction barring future infringement and regarding exercise of patents, in order to maintain order in IP markets and lead the markets' growth in a socially beneficial direction. Parties' assessment of the remedies a court might award in the case of a lawsuit heavily influences the value of patents, and their licence or transfer behaviour. For example, in 2006, the US Supreme Court ruled in eBay v. MercExchange that district courts may no longer automatically grant a permanent injunction barring future infringement following a finding of infringement, but must consider traditional principles of equity. In Quanta Computer Inc. v. LG Electronics, the Supreme Court affirmed the exhaustion doctrine, even where the initial patent licence purported to limit the rights transferred to subsequent purchasers of a covered product. In Japan, the Ministry of Economy, Trade and Industry revised the "Interpretive Guidelines on Electronic Commerce and Information Property Trading" in May 2007, and stated in it that the "abuse of right" principle ruled in the Japanese Civil Code might be applicable to the exercise of patent rights on software when such an exercise of patent rights deviates from the purpose of the Patent Law by, for example, discouraging innovation (METI, 2007).

Excessively weak patents might deter business investment in $R \& D$, as it becomes too easy for an imitator to undercut the inventor's market price. Weak patents may also encourage secrecy and deter the diffusion of knowledge and technology. Conversely, excessively strong patents may open the door to undesired anti-innovative behaviour by patent holders, who may use their titles not as a basis for producing and selling goods but, instead, as a tool just for extracting unreasonable revenue from existing inventions marketed by other companies (OECD, 2004). For such entities, an injunction and the potentially serious damage awards arising from violation of patents can be employed as a bargaining chip to charge exorbitant fees to companies that seek to obtain licences to use the patent. Thus, both under- and over-compensation of patentees will harm innovation. Hence, designing a properly balanced patent enforcement system might be critical to develop efficient markets for IP and facilitate smooth circulation of IP.

\subsection{Financial incentives for patent licensing}

Some countries have also introduced specific financial incentives for patent licensing. For example, the Intellectual Property Office in the United Kingdom (UKIPO) provides a License-of-right programme to facilitate the exploitation of patents. The License-of-right programme offers patent holders a $50 \%$ discount on the renewal fee to maintain their patent rights in exchange for their commitment to offer non-exclusive licences to anyone who asks for them. The German Patent and Trade Mark Office (DPMA) has also introduced a similar financial incentive programme which allows patent owners who declare they are prepared to licence their patent to anyone in return for appropriate compensation, to get a $50 \%$ discount on the renewal fee for the patent. Additionally, as described above, UKIPO and DPMA provide information about such licensable patents through online databases so that anyone can easily identify patents that are available for licence.

In addition, a number of countries use their tax systems to encourage patenting and licensing. One way to do this is by offering tax reductions on royalties generated by patent licences. In general, countries in Europe, North America and East Asia treat patent royalties similarly in their tax codes: royalties received are treated as taxable income, which is taxed at the prevailing corporate income tax rates; expenses related to patenting, purchase of patents and payment of patent royalties are deductible from taxable business income and not taxed (OECD, 2006). However, some countries provide special incentives for patenting income. The Irish government offers a full tax exemption for royalty income generated by the licensing of patents that result from R\&D conducted in Ireland. Switzerland, Hungary and Korea offer a partial deduction, typically 50\%, in income tax. France offers reductions in capital gains tax under certain conditions (Warda, 2006). 


\subsection{Improvement in the quality of patent rights at the global level}

In the open innovation era, patents are expected to play a role as a means not only for excluding others from using patented technology but for transferring knowledge and technologies. That is, a patent is expected to act as the vehicle to circulate knowledge and technologies. Therefore, strengthening trust in technology transaction by securing the quality of patents is an essential requirement for facilitating knowledge and technology diffusion. To achieve this, government authorities are making efforts to improve patent quality. In the United States, for example, the United States Patent and Trademark Office (USPTO) has released a "2007-2012 Strategic Plan" with the aim of improving patent quality and streamlining procedures (USPTO, 2007). In Japan, the Japan Patent Office (JPO) has released "New Intellectual Property Policy for Pro-Innovation" and described the importance of improving patent quality in it (JPO, 2008a). The European Commission (EC) has published communications and also described the importance of improving patent quality (EC, 2007; EC, 2008).

In addition, patent offices are developing co-operation on patent examinations aimed at reducing the examination workload and improving the quality of issued patents. For instance, major patent offices including USPTO, JPO, EPO, KIPO, UKIPO, and GPTO are conducting the substantial examination cooperation programme called "Patent Prosecution Highway programme". Patent Prosecution Highway programme is an initiative for providing accelerated and high-quality patent examination, by enhancing the sharing of information about substantial examination between patent offices. Furthermore, comparative studies of examination practices have been conducted in various technology fields to improve comparability of examination practices across patent offices and improve the quality of issued patents. These co-operative activities among patent offices may be essential to improve the quality of patents at the international level. Therefore, patent offices are expected to enhance the frameworks for examination cooperation.

From 2007 to 2009, the USPTO ran a pilot project called Peer-to-Patent in association with the New York Law School Institute for Information Law and Policy. Peer-to-Patent in an online system that aims to improve the quality of patents by enabling the public to submit prior art and commentary relevant to claims of pending patent applications to the USPTO. During the two-year pilot period, more than 2600 people have registered to become a peer reviewer. More than 180 patent applications were posted to the Peer-toPatent website by 73 applicants and reviewed by the public. Since Peer-to-Patent was launched, 66 office actions have been issued by the USPTO for applications that have undergone peer review. In total, the USPTO used Peer-to-Patent submitted prior art references to reject 1 or more claims in 18 patent applications (Center for Patent Innovations at New York Law School, 2009). According to the survey conducted at the end of the second year, of these 18 office actions, 8 used prior art that was not found by USPTO examiners. More than $50 \%$ of examiners reported that prior art submitted by Peer-to-Patent was helpful. In Japan, the JPO also ran a Peer-to-Patent pilot in 2008. In the pilot programme, 39 applications were posted on the Japanese Peer-to-Patent website by 16 companies. More than 250 people registered as a peer reviewer and 137 prior art documents were submitted against 38 applications - 120 out of 137 were submitted to JPO. As of April 2009, 19 prior art documents submitted through Peer-to-Patent review were cited in office actions in 13 applications.

\subsection{Development of patent circulation/sharing platforms}

Governments are starting to encourage the establishment of patent circulation/sharing platforms, where any entity can access and share promising patented technologies with the aim of promoting innovation by facilitating knowledge diffusion. In Japan, as discussed above, the Japanese government and 16 companies jointly established the Innovation Network Corporation of Japan (INCJ), an investment company focused on investing in innovative businesses and technologies. The INCJ will invest a portion of its funds in entities such as IP funds that acquire promising patents and develop strong patent portfolios. 
Such IP funds will collect patents from universities, research institutions and companies. They then encourage dissemination of the patented technologies by broadly licensing their patents to those who wish to use the patented technology. Through this approach, the Japanese government expects to facilitate the circulation/sharing of technologies across organisational boundaries.

\section{Box 15. The National Center for Industrial Property Information and Training (INPIT)}

The National Center for Industrial Property Information and Training (INPIT) is an independent administrative institution established in 2001. INPIT offers a variety of IP-related services, ranging from provision of comprehensive information on industrial property to developing IP-related human resources. As a part of its services, INPIT provides comprehensive support activities to promote patent licensing and establish a patent licensing market.

The JPO launched the project called Measurement for Encouraging Patent Licensing in 1997 with the aim to develop an environment where SMEs and venture companies can create new businesses by making use of licensable patents held by universities, research institutes, and private companies. In 2001, the INPIT took over the project from JPO. About JPY 2.8 billion (about USD 30 million) was allocated to this project in FY2008. The project includes many programmes aimed at boosting patent licensing activities, such as dispatch of patent licensing advisors to intellectual property centers operated by local governments and technology licensing offices, provision of the patent licensing database, and support activities for fostering patent licensing businesses. Outlines of the Patent Licensing Advisor programme, the Patent Licensing Database programme and support activities for fostering patent licensing businesses follows:

\section{Dispatch of patent licensing advisor}

In response to requests from local governments and university technology transfer offices (TLOs), INPIT dispatches patent licensing advisors to intellectual property centers operated by local government and TLOs with the aim of supporting local SMEs, universities, and research institutes in dealing with patent licenses. Patent licensing advisors are IP experts with a considerable knowledge and experience of intellectual property rights and technology transfers, and are usually appointed among those who have a long experience working in licence departments or intellectual property departments in private companies. Patent licensing advisors first collect information about licensable patents held by companies, universities, and research institutes, as well as information on companies' needs for external technologies and patents, by visiting local companies, universities and research institutes. Then they attempt to match potential licensees who wish to acquire a certain external technology to boost business with potential licensors who own licensable patents that fit the potential licensees' needs. As described above, the Patent Licensing Advisor programme is reported to have undertaken more than 12000 IP-related licensing transactions since it began in 1997. According to the INPIT, as of end 2007, the estimated economic impact of this project reached more than JPY 267 billion (about USD 2.8 billion) (JPO, 2008b).

\section{Provision of the patent licensing database}

In order to promote patent licensing activities, INPIT also provides the patent licensing database which contains information on licensable Japanese patents registered by companies, universities, and research institutes. Anyone who wishes to license their patents can register the information about their licensable patents including patent number, terms and conditions of licensing, and contact address, in the patent licensing database free of charge through the Internet. The patent licensing database allows licensees to freely access the information about licensable patents by providing a search interface through the Internet. As of August 2009, the patent licensing database stored information on about 45500 licensable Japanese patents (about 19000 licensable patents from companies, about 2100 licensable patents from individual inventors, and about 24400 licensable patents from universities and research institutes).

\section{Support activities for fostering patent licensing businesses}

In order to foster technology-transfer businesses, including patent licensing businesses in Japan, INPIT organises a series of seminars and symposiums focusing on topics related to IP transactions and IP transfer businesses, and also holds the Patent Business Market wherein SMEs and TLOs can explain their patented technology and business plans, and invite offers for licensing, business alliances and investment. Additionally, INPIT organises International Patent Licensing Seminars to provide opportunities for those who are engaging in technology transfer or IP transfer businesses in Japan and other countries to exchange information and develop a human network. Furthermore, INPIT develops and delivers a Technology Transfer Company Directory through its website with the aim of supporting entities that need help from technology and IP transfer specialists to find appropriate partners whose services match their business strategy. 


\section{Provision of the research tool patent database}

In April 2009, INPIT started to provide the research tool patent database which gives information about licensable research tool patents owned by universities, research institutes, and private businesses, with the aim of advancing the research activities by facilitating the diffusion of research tool patents which cover fundamental technologies. According to the "Guidelines for Facilitating the Use of Research Tool Patents in the Life Sciences" which were published by the Council for Science and Technology Policy in Japan in March 2007, the research tool patents are defined as Japanese patents granted with respect to products or methods to be used as tools for conducting research in life sciences, e.g. patents for test animals and plants, cell lines, monoclonal antibody, and screening methods. The research tool patent database stores and provides information on registered licensable research tool patents such as identities of patent owners, issued number, and terms and conditions of licensing. As of August 2009, the database allows anyone to freely access through the Internet the information about more than 850 research tool patents.

\section{CHALLENGES FROM THE EMERGING IP MARKETPLACE}

In order to promote innovation throughout the entire society in this open innovation era, enhancing the smooth circulation of IP, notably patents, is critical. In these circumstances, both public authorities and private IP specialist firms are playing an important role for facilitating the diffusion of knowledge and technology, as described above. In particular, the activities of IP specialist firms will become more crucial.

For example, IP brokers and IP consulting firms can facilitate the circulation of knowledge and technology protected by patents by providing useful information about possible deals (Benassi and Di Minin, 2009). They also help their clients exploit patents by providing patent portfolio development support, licensing support, and legal assistance. The business model like IP-fund manager may encourage their clients to commercialise their valuable technologies, develop further innovative technologies, or launch licensing programmes by providing money for their IP. Particularly, the business models like invention creation investment funds, which invest money raised from capital markets in R\&D activities regarding future-oriented technologies or interdisciplinary science, in return for patents generated from such activities, have the potential to significantly contribute to scientific or technological breakthroughs as well as facilitating the diffusion of such knowledge and technology through IP licensing programme. Such businesses as patent pool administrator, which enables willing licensees to obtain the licences of a number of essential patents necessary for implementing certain technologies from multiple patent owners in a single transaction, could promote development of products particularly in areas like ICT where most products consist of multiple components involving various patented technologies. The business model patent auction might contribute to improve transparency of transaction processes and predictability of the market value of patents as well as facilitating patent transactions. Thus, the role of IP specialist firms is increasingly critical to the diffusion of knowledge and technology.

At the same time, however, the evolution of IP markets and activities of IP specialist firms poses some significant challenges to society, especially to innovative companies and policy makers. Some argue that the activities of some IP-centric players have the potential to play a negative role in innovation. Activities such as those that use patents only as leverage for licence or infringement claims have been the most controversial. In some cases these 'purely patents' businesses may allege infringement by a large number of companies, even across an entire industry or market, and seek to achieve a financial settlement with each, such as via a licensing agreement (EPO, 2007). Also, some argue the presence of poor quality patents is one of the causes of this kind of problem. For instance, asserting a questionable patent that claims a single routine in a software program to hold up production of the entire software program can deter follow-on innovation and unjustifiably raise costs to businesses and, ultimately, to consumers (FTC, 2003). Now, Governments are expected to lead the development of IP markets in the most socially 
beneficial directions, while companies are forced to develop strategic IP management which is integrated with their overall business plan.

In order to facilitate the circulation of IP and promote innovation, it will be very important that policy makers maintain the order of the IP markets by carefully prohibiting anti-innovative activities, in addition to encouraging the development of markets for IP and businesses of IP-specialist firms. Since the characteristics of each IP exploitation activity regarded as anti-innovative are varied and differ in each case, there doesn't seem to be a specific policy that can prohibit all anti-innovative patent exploitation activities. Therefore policy makers should develop comprehensive policies which include actions in various policy areas such as IP regime, competition and tax policy. In particular policy makers should explore ways of: enhancing transparency and predictability of IPR transactions (e.g. establishing a shared understanding of reasonable market prices by encouraging the disclosure of patent licensing and sales information); strengthening trust in technology transactions by securing the quality of patents; establishing properly tuned regulations against anti-innovative activities in IPR marketplaces (e.g. finding appropriate competition enforcement policies with respect to IPR transactions, and finding appropriate patent remedy policies). 
Annex 1: Activities of some IP specialist firms

\begin{tabular}{|c|c|c|c|}
\hline $\begin{array}{l}\text { Companyl } \\
\text { Organisation }\end{array}$ & $\begin{array}{l}\text { Date of } \\
\text { Creation }\end{array}$ & $\begin{array}{l}\text { Volume of activity (number of employees, } \\
\text { transaction records, etc.) }\end{array}$ & Business model \\
\hline IP Capital Group & 1998 & $\begin{array}{l}\text { - delivered over } 450 \text { IP engagements to companies } \\
\text { that seek to develop and execute IP strategies, } \\
\text { strengthen and monetise IP portfolios, and establish } \\
\text { and implement Intellectual Asset Management } \\
\text { practices }\end{array}$ & $\begin{array}{l}\text { IP management } \\
\text { support }\end{array}$ \\
\hline Thinkfire & 2001 & $\begin{array}{l}\text { - } 25 \text { employees (as of 2007) } \\
\text { - provided IP advisory and transaction services to } \\
\text { over } 80 \text { global technology companies and } \\
\text { investment firms (e.g. Blackstone Group, Hewlett- } \\
\text { Packard, Kodak, NEC, Nokia) }\end{array}$ & $\begin{array}{l}\text { - IP management } \\
\text { support } \\
\text {-IP brokerage }\end{array}$ \\
\hline IPotential & 2003 & $\begin{array}{l}\text { - as of January } 2009 \text {, completed } 123 \text { transactions, } \\
\text { sold } 3895 \text { patents/patent applications } \\
\text { - more than USD } 265 \text { million in completed } \\
\text { transaction value since } 2003\end{array}$ & $\begin{array}{l}\text { - IP management } \\
\text { support } \\
\text {-IP brokerage }\end{array}$ \\
\hline InnoCentive & 2001 & $\begin{array}{l}\text { - as of April 2009, } 32 \text { employees } \\
\text { - more than } 160000 \text { registered problem solvers } \\
\text { - more than } 800 \text { problems have been posted on } \\
\text { InnoCentive's website and almost } 400 \text { solutions } \\
\text { have been found by leveraging a network of } \\
\text { problem solvers } \\
\text { - almost USD } 20 \text { million in awards have been } \\
\text { posted and almost USD } 4 \text { million in awards have } \\
\text { been paid to successful problem solvers }\end{array}$ & $\begin{array}{l}\text { Online } \\
\text { knowledge/IP } \\
\text { marketplace }\end{array}$ \\
\hline NineSigma & 2000 & $\begin{array}{l}\text { - conducted more than } 1500 \text { open innovation } \\
\text { projects requested by its global } 1000 \text { clients by } \\
\text { leveraging a network of solution providers in } \\
135 \text { countries } \\
\text { - received over } 20000 \text { innovation proposals from } \\
\text { solution providers } \\
\text { - facilitated over USD } 12 \text { million in contract awards } \\
\text { between its clients and solution providers }\end{array}$ & $\begin{array}{l}\text { Online } \\
\text { knowledge/IP } \\
\text { marketplace }\end{array}$ \\
\hline YourEncore & 2003 & $\begin{array}{l}\text { - provides solutions posted by client companies by } \\
\text { leveraging the expertise of more than } 5000 \text { retired } \\
\text { and veteran scientists and engineers } \\
\text { - completed more than } 600 \text { engagements for client } \\
\text { companies }\end{array}$ & $\begin{array}{l}\text { Online } \\
\text { knowledge/IP } \\
\text { marketplace }\end{array}$ \\
\hline yet2.com & 1999 & $\begin{array}{l}\text { - over } 120000 \text { registered marketplace users } \\
\text { - provides more than } 5000 \text { available technologies } \\
\text { through its online marketplace }\end{array}$ & $\begin{array}{l}\text { Online } \\
\text { knowledge/IP } \\
\text { marketplace }\end{array}$ \\
\hline UTEK & 1996 & $\begin{array}{l}\text { - } 110 \text { employees } \\
\text { - manages } 6 \text { online technology marketplaces: } \\
\text { pharmalicensing.com, genericlicensing.com, } \\
\text { Knowledge Express, PHARMA-TRANSFER, } \\
\text { TechEx, TekScout. }\end{array}$ & $\begin{array}{l}\text { Online } \\
\text { knowledge/IP } \\
\text { marketplace }\end{array}$ \\
\hline
\end{tabular}


DSTI/DOC(2009)9

\begin{tabular}{|c|c|c|c|}
\hline Fluid Innovation & 2005 & $\begin{array}{l}\text { - as of June } 2008,4 \text { full-time employees } \\
\text { - about } 1000 \text { companies are profiled on the site } \\
\text { - more than } 120 \text { softwares are on sale on its online } \\
\text { marketplace }\end{array}$ & $\begin{array}{l}\text { Online } \\
\text { knowledge/IP } \\
\text { marketplace }\end{array}$ \\
\hline Ocean Tomo & 2003 & $\begin{array}{l}\text { - held } 10 \text { live auctions across the US and Europe } \\
\text { realising over USD } 100 \text { million in transactions }\end{array}$ & $\begin{array}{l}\text { Live IP auction, } \\
\text { Online marketplace }\end{array}$ \\
\hline FreePatentAuction & 2004 & $\begin{array}{l}\text { - provides more than } 1600 \text { available patents } \\
\text { through its website }\end{array}$ & $\begin{array}{l}\text { IP auction, Online } \\
\text { marketplace }\end{array}$ \\
\hline $\begin{array}{l}\text { Stanford University } \\
\text { Office of Technology } \\
\text { Licensing }\end{array}$ & 1970 & $\begin{array}{l}\text { - closed } 107 \text { new licence agreements in fiscal year } \\
2008 \\
\text { - received USD } 62.5 \text { million in royalty revenue from } \\
546 \text { technologies in fiscal year } 2008\end{array}$ & $\begin{array}{l}\text { University } \\
\text { technology } \\
\text { licensing/transfer }\end{array}$ \\
\hline Flintbox & 2003 & $\begin{array}{l}\text { - online database containing } 1400 \text { available } \\
\text { patents }\end{array}$ & $\begin{array}{l}\text { - Online } \\
\text { knowledge/IP } \\
\text { marketplace } \\
\text { - University } \\
\text { technology } \\
\text { licensing/transfer }\end{array}$ \\
\hline MPEG LA & 1996 & $\begin{array}{l}\text { - as of April 2009, manages } 8 \text { patent pools (joint } \\
\text { licensing programmes) } \\
\text { - MPEG-2 ( } 25 \text { patent owners, } 875 \text { patents in } \\
57 \text { countries, } 1614 \text { licensees) } \\
\text { - ATSC ( } 7 \text { patent owners, } 110 \text { patents in } \\
21 \text { countries, } 98 \text { licensees) } \\
\text { - AVC/H. } 264 \text { ( } 24 \text { patent owners, } 681 \text { patents in } 41 \\
\text { countries, } 587 \text { licensees) } \\
\text { - VC-1 ( } 17 \text { patent owners, } 503 \text { patents in } \\
32 \text { countries, } 111 \text { licensees) } \\
\text { - MPEG-4 Visual ( } 29 \text { patent owners, } 862 \text { patents in } \\
51 \text { countries, } 608 \text { licensees) } \\
\text { - MPEG-2 Systems ( } 8 \text { patent owners, } 185 \text { patents } \\
\text { in } 29 \text { countries, } 68 \text { licensees) } \\
\text { - IEEE } 1394 \text { (10 patent owners, } 268 \text { patents in } 22 \\
\text { countries, } 388 \text { licensees) } \\
\text { - LTE (under development) }\end{array}$ & $\begin{array}{l}\text { Patent pool } \\
\text { (MPEG-2, ATSC, } \\
\text { AVC/H.264, VC-1, } \\
\text { MPEG-4 Visual, } \\
\text { MPEG-2 Systems, } \\
\text { IEEE 1394, LTE) }\end{array}$ \\
\hline
\end{tabular}




\begin{tabular}{|c|c|c|c|}
\hline Via licensing & 2002 & $\begin{array}{l}\text { - manages } 11 \text { patent pools (joint licensing } \\
\text { programmes) } \\
\text { - Advanced Audio Coding ( } 12 \text { patent owners, more } \\
\text { than } 400 \text { licensees) } \\
\text { - AGORA-C ( } 4 \text { patent owners) } \\
\text { - Digital Radio Mondiale (14 patent owners, } \\
14 \text { licensees) } \\
\text { - IEEE } 802.11 \text { ( } 8 \text { patent owners) } \\
\text { - DVB-MHP (7 patent owners) } \\
\text { - MPEG-2 AAC (5 patent owners, } 125 \text { licensees) } \\
\text { - MPEG-4 SLS } \\
\text { - MPEG Surround Standard } \\
\text { - Near Field Communication (4 patent owners) } \\
\text { - tru2way/OCAP ( } 7 \text { patent owners, } 6 \text { licensees) } \\
\text { - TV-Anytime (8 patent owners) }\end{array}$ & $\begin{array}{l}\text { Patent pool } \\
\text { (Advanced Audio } \\
\text { Coding, AGORA-C, } \\
\text { Digital Radio } \\
\text { Mondiale, IEEE } \\
\text { 802.11, DVB-MHP, } \\
\text { MPEG-2 AAC, } \\
\text { MPEG-4 SLS, } \\
\text { MPEG Surround } \\
\text { Standard, Near } \\
\text { Field } \\
\text { Communication, } \\
\text { tru2way/OCAP, } \\
\text { TV-Anytime) }\end{array}$ \\
\hline SISVEL & 1982 & $\begin{array}{l}\text { - manages } 10 \text { patent pools (joint licensing } \\
\text { programmes) } \\
\text { - MPEG Audio (6 patent owners, more than } 1000 \\
\text { licensees) } \\
\text { - DVB-T (4 patent owners, } 173 \text { licensees) } \\
\text { - ATSS (patent owner: Edico (a SISVEL subsidiary), } \\
20 \text { licensees) } \\
\text { - WSS (5 patent owners, } 23 \text { licensees) } \\
\text { - TOPteletext ( } 5 \text { patent owners, } 40 \text { licensees) } \\
\text { - UHF-RFID ( } 6 \text { patent owners) } \\
\text { - CDMA2000 ( } 5 \text { patent owners) } \\
\text { - DECT (patent owner: Telecom Italia) } \\
\text { - DVB-H (under development) } \\
\text { - DVB-T2 (under development) }\end{array}$ & $\begin{array}{l}\text { Patent pool (MPEG } \\
\text { Audio, DVB-T, } \\
\text { ATSS, WSS, } \\
\text { TOPteletext, UHF- } \\
\text { RFID, CDMA2000, } \\
\text { DECT, DVB-H, } \\
\text { DVB-T2) }\end{array}$ \\
\hline ULDAGE & 2006 & $\begin{array}{l}\text { - manages } 2 \text { patent pools (licensing programmes) } \\
\text { consisting of more than } 300 \text { Japanese essential } \\
\text { patents owned by } 15 \text { licensors } \\
\text { - sub-licenses to more than } 120 \text { licensees }\end{array}$ & $\begin{array}{l}\text { Patent pool (ARIB, } \\
\text { CATV) }\end{array}$ \\
\hline Open Patent Alliance & 2008 & $\begin{array}{l}\text { - launched WiMAX patent pool (Via Licensing will } \\
\text { facilitate the formation and administration of the } \\
\text { pool on behalf of the Open Patent Alliance) }\end{array}$ & $\begin{array}{l}\text { Patent pool } \\
\text { (WiMAX) }\end{array}$ \\
\hline 3G Licensing & 2004 & $\begin{array}{l}\text { - manages W-CDMA patent licensing programme } \\
\text { (12 patent owners, more than } 300 \mathrm{~W} \text {-CDMA } \\
\text { essential patent families) }\end{array}$ & $\begin{array}{l}\text { Patent pool/Patent } \\
\text { platform (W-CDMA) }\end{array}$ \\
\hline InterDigital, Inc. & $\begin{array}{l}1972 \\
\text { (started } \\
\text { patent- } \\
\text { license- } \\
\text { based } \\
\text { business in } \\
\text { 1990s) }\end{array}$ & $\begin{array}{l}\text { - approximately } 400 \text { employees } \\
\text { - holds more than } 3000 \text { patents, and } 9000 \text { patent } \\
\text { applications related to wireless communication } \\
\text { technologies } \\
\text { - established patent licence agreements covering } \\
\text { some technology standards such as CDMA,W- } \\
\text { CDMA with almost } 40 \text { manufacturers of wireless } \\
\text { equipment (e.g. Apple, LG, NEC, RIM, Nokia, } \\
\text { Samsung) } \\
\text { - acquired over USD } 200 \text { million licensing revenue } \\
\text { in } 2008\end{array}$ & $\begin{array}{l}\text { IP/technology } \\
\text { development and } \\
\text { licensing }\end{array}$ \\
\hline
\end{tabular}




\begin{tabular}{|c|c|c|c|}
\hline Qualcomm & 1985 & $\begin{array}{l}\text { - generated USD } 3.98 \text { billion by licensing its } \\
\text { technologies and IPR in fiscal year } 2008 \\
\text { - its IP portfolio includes more than } 10100 \text { United } \\
\text { States patents for wireless technologies } \\
\text { - licenses its IP portfolio to more than } 165 \\
\text { telecommunications equipment manufacturers }\end{array}$ & $\begin{array}{l}\text { IP/technology } \\
\text { development and } \\
\text { licensing }\end{array}$ \\
\hline Rambus & 1990 & $\begin{array}{l}\cdot \text { generated USD } 127 \text { million by licensing its } \\
\text { technologies and IPR in } 2008 \text { (USD } 154 \text { million in } \\
2007, \text { USD } 169 \text { million in 2006) } \\
\text { - owns more than } 740 \text { US and foreign-issued } \\
\text { patents, and approximately } 500 \text { patent applications }\end{array}$ & $\begin{array}{l}\text { IP/technology } \\
\text { development and } \\
\text { licensing }\end{array}$ \\
\hline WiLAN & $\begin{array}{l}1992 \\
\text { (chose to } \\
\text { focus its } \\
\text { business } \\
\text { on } \\
\text { developing, } \\
\text { protecting } \\
\text { and } \\
\text { monetising } \\
\text { patented } \\
\text { inventions } \\
\text { in 2006) }\end{array}$ & $\begin{array}{l}\text { - licensing revenue USD } 26.6 \text { million in fiscal year } \\
2008 \\
\text { - licensed its technology and IPR to over } \\
190 \text { companies } \\
\text { - holds over } 670 \text { issued and pending patents, more } \\
\text { than } 370 \text { of which relate to wireless technologies }\end{array}$ & $\begin{array}{l}\text { IP/technology } \\
\text { development and } \\
\text { licensing }\end{array}$ \\
\hline $\begin{array}{l}\text { Avistar } \\
\text { Communication }\end{array}$ & 1993 & $\begin{array}{l}\text { - } 66 \text { US and foreign patents } \\
\text { - initiated a patent licensing \& IP assertion } \\
\text { programme } \\
\text { - in } 2004 \text {, settled with Polycom for USD } 27 \text { million } \\
\text { plus cross-licensing }\end{array}$ & $\begin{array}{l}\text { IP/technology } \\
\text { development and } \\
\text { licensing }\end{array}$ \\
\hline InterTrust & 1990 & $\begin{array}{l}\text { - } 376 \text { employees in } 2000 \\
\text { - approximately } 40 \text { employees in } 2009 \\
\text { - holds over } 100 \text { issued patents, and has over } 300 \\
\text { pending patent applications worldwide } \\
\text { - licenses patent portfolio to Sony for } 24 \text { million in } \\
2002 \\
\text { - entered into patent litigation with Microsoft in } 2002 \\
\text { - acquired by SonyPhilips in } 2003 \text { for USD } \\
453 \text { million } \\
\text { - Microsoft settles in } 2004 \text { for USD } 440 \text { million }\end{array}$ & $\begin{array}{l}\text { IP/technology } \\
\text { development and } \\
\text { licensing }\end{array}$ \\
\hline Intellectual Ventures & 2000 & $\begin{array}{l}\text { - about } 550 \text { employees } \\
\text { - raised around USD } 5 \text { billion from investors } \\
\text { - spent more than USD } 1 \text { billion } \\
\text { - owns about } 27000 \text { assets (issued patents and } \\
\text { patent applications) } \\
\text { - returned approximately USD } 1 \text { billion to its } \\
\text { investors }\end{array}$ & $\begin{array}{l}- \text { IP investment } \\
\text { fund } \\
\cdot \text { Technology/IP } \\
\text { development and } \\
\text { licensing } \\
\text { - IP aggregation } \\
\text { and licensing }\end{array}$ \\
\hline
\end{tabular}




\begin{tabular}{|c|c|c|c|}
\hline Acacia Technologies & $\begin{array}{l}1992 \\
\text { (started } \\
\text { patent } \\
\text { licence- } \\
\text { based } \\
\text { business in } \\
2003 \text { ) }\end{array}$ & $\begin{array}{l}\text { - } 50 \text { employees (as of 2008) } \\
\text { - owns over } 100 \text { patent portfolios } \\
\text { - generating revenues from } 55 \text { of its licensing } \\
\text { programmes } \\
\text { - completed more than } 650 \text { licences } \\
\text { - has approximately USD } 50 \text { million in working } \\
\text { capital to bring and sustain legal actions against } \\
\text { infringers } \\
\text { - generated about USD } 48 \text { million from its licensing } \\
\text { programmes in } 2008\end{array}$ & $\begin{array}{l}\text { - IP/Technology } \\
\text { development and } \\
\text { licensing } \\
\text { - IP aggregation } \\
\text { and licensing }\end{array}$ \\
\hline $\begin{array}{l}\text { Rembrandt IP } \\
\text { Management }\end{array}$ & 2004 & - raised USD 150 million to invest in patents & $\begin{array}{l}\text { IP aggregation and } \\
\text { licensing }\end{array}$ \\
\hline RPX corp & 2008 & $\begin{array}{l}\cdot \text { acquired more than } 150 \text { US patents and more } \\
\text { than } 60 \text { US applications } \\
\text { - bought more than USD } 90 \text { million worth of patents }\end{array}$ & $\begin{array}{l}\text { Defensive patent } \\
\text { aggregation }\end{array}$ \\
\hline Allied Security Trust & 2008 & $\begin{array}{l}\text { - USD } 250000 \text { to join AST and USD } 5 \text { million to } \\
\text { fund buying patents }\end{array}$ & $\begin{array}{l}\text { Defensive patent } \\
\text { aggregation }\end{array}$ \\
\hline $\begin{array}{l}\text { Open Invention } \\
\text { Network }\end{array}$ & 2005 & $\begin{array}{l}\text { - acquired more than } 275 \text { patents and patent } \\
\text { applications }\end{array}$ & $\begin{array}{l}\text { Defensive patent } \\
\text { aggregation }\end{array}$ \\
\hline Eco-Patent Commons & 2008 & $\begin{array}{l}\text { - pooling about } 100 \text { eco-friendly patents pledged by } \\
9 \text { companies }\end{array}$ & $\begin{array}{l}\text { Initiative for free } \\
\text { sharing of patents }\end{array}$ \\
\hline DRI Capital & - & $\begin{array}{l}\text { - investment management company, focused on } \\
\text { investing in royalty stream in the healthcare } \\
\text { industry, with over USD1 billion under management } \\
\text { - currently manages two funds: the Royalty } \\
\text { Monetization Fund and the Structured Finance } \\
\text { Fund } \\
\text { - acquired over USD } 850 \text { million in royalty-based } \\
\text { cash flows on commercialised products (in } 2007 \\
\text { alone, deployed about USD } 450 \text { million with royalty } \\
\text { acquisitions on products such as Enbrel, Flumist, } \\
\text { Preotact and PEG-INTRON) }\end{array}$ & $\begin{array}{l}\text { IP based financing } \\
\text { (IP structured } \\
\text { finance) }\end{array}$ \\
\hline Royalty Pharma & 1996 & $\begin{array}{l}\text { - investment management company focused on } \\
\text { investing in royalty stream in the healthcare industry } \\
\text { - in } 2007 \text {, realised royalty revenue of } \\
\text { USD } 385 \text { million (USD } 200 \text { million in } 2006 \text {, } \\
\text { USD } 161 \text { million in 2005, USD } 122 \text { million in } 2004 \text {, } \\
\text { USD } 67 \text { million in 2003) } \\
\text { - has acquired various royalty streams (USD } 700 \\
\text { million purchase of the Lyrica } ₫ \text { royalty from } \\
\text { Northwestern University, USD } 650 \text { million purchase } \\
\text { of the Remicade } @ \text { royalty from New York } \\
\text { University, etc.) }\end{array}$ & $\begin{array}{l}\text { IP based financing } \\
\text { (IP structured } \\
\text { finance) }\end{array}$ \\
\hline
\end{tabular}




\begin{tabular}{|c|c|c|c|}
\hline $\begin{array}{l}\text { Cowen Healthcare } \\
\text { Royalty Partners }\end{array}$ & 2007 & $\begin{array}{l}\text { - focused on investing in royalty stream in the } \\
\text { healthcare industry, with over USD } 500 \text { million } \\
\text { under management } \\
\text { - invested USD } 65 \text { million in Dyax Corp, USD } 52.5 \\
\text { million in ÆEterna Zentaris, USD } 22.5 \text { million in Artes } \\
\text { Medical, USD } 105 \text { million in LifeCycle Pharma }\end{array}$ & $\begin{array}{l}\text { IP based financing } \\
\text { (IP structured } \\
\text { finance) }\end{array}$ \\
\hline Paul Capital Partners & 1999 & $\begin{array}{l}\text { - } 15 \text { employees } \\
\text { - investment funds, focused on investing in the } \\
\text { healthcare industry, with USD } 1.6 \text { billion in capital } \\
\text { under management } \\
\text { - has closed about } 40 \text { investments (e.g. Aston } \\
\text { University, Imperial College, Cancer Research } \\
\text { Technology) }\end{array}$ & $\begin{array}{l}\text { IP based financing } \\
\text { (IP structured } \\
\text { finance) }\end{array}$ \\
\hline $\begin{array}{l}\text { Patent Finance } \\
\text { Consulting }\end{array}$ & 2004 & $\begin{array}{l}\text { - manages JPY } 10 \text { billion (about USD } 11 \text { million) } \\
\text { fund } \\
\text { • invested in } 4 \text { projects }\end{array}$ & $\begin{array}{l}\text { IP based financing } \\
\text { (IP structured } \\
\text { finance) }\end{array}$ \\
\hline $\begin{array}{l}\text { Innovation Network } \\
\text { Corporation of Japan }\end{array}$ & 2009 & $\begin{array}{l}\cdot \text { has an investment capacity of about } \\
\text { JPY } 900 \text { billion (about USD } 9.6 \text { billion) } \\
\cdot \text { plan to invest in innovative inventions }\end{array}$ & $\begin{array}{l}\text { IP based financing } \\
\text { (innovation } \\
\text { investment fund) }\end{array}$ \\
\hline $\begin{array}{l}\text { Altitude Capital } \\
\text { Partners }\end{array}$ & 2005 & $\begin{array}{l}\text { - raised USD } 250 \text { million to invest in businesses } \\
\text { holding valuable intellectual property assets } \\
\text { - as of September } 2008 \text {, closed } 16 \text { transactions } \\
\text { investing/committing about USD } 120 \text { million } \\
\text { - invested USD } 8 \text { million in Deep Nines } \\
\text { - invested USD } 35 \text { million in VISTO corp. } \\
\text { - invested USD } 6.25 \text { million in MercExchange }\end{array}$ & IP based financing \\
\hline Coller IP Capital & - & - plan to invest USD 200 million a year in IP & IP based financing \\
\hline NW Patent Funding & 2006 & - manages USD 50-100 million fund & IP based financing \\
\hline $\begin{array}{l}\text { New Venture Partners } \\
\text { LLC }\end{array}$ & 2001 & $\begin{array}{l}\text { - has founded and funded more than } 50 \text { technology } \\
\text { ventures from the R\&D labs and business units of } \\
\text { global technology corporations } \\
\text { - manages USD } 275 \text { million fund }\end{array}$ & IP based financing \\
\hline
\end{tabular}




\section{BIBLIOGRAPHY}

Altitude Capital Partners (2007), Altitude Capital Partners Completes First-Ever Dual Private Equity Investment/ Intellectual Property Investment in Deep Nines, Inc., Altitude Capital Partners, www.altitudecp.com/pdf/DeepNines\%20final.pdf.

Barron, R.J. (2008), "Venture Funded IP Litigation Funds (VFLP-IP) What, Who, How", presentation at Wisconsin Intellectual Property Law Association meeting, 16 September 2008, Milwaukee, WI.

Benassi, M. and A. Di Minin (2009), "Playing in between: patent brokers in markets for technology", R\&D Management, Vol. 39, No. 1, January 2009, pp. 68-86, Blackwell Publishing.

Center for Patent Innovations at New York Law School (2009), Peer to Patent Second Anniversary Report, Center for Patent Innovations at New York Law School, New York, NY.

Chesbrough, H. (2003), Open Innovation: The New Imperative for Creating and Profiting from Technology, Harvard Business School Press, Boston, MA.

Chesbrough, H. (2006a), Open Business Models: How to Thrive in the New Innovation Landscape, Harvard Business School Press, Boston, MA.

Chesbrough, H. (2006b), Emerging Secondary Markets for Intellectual Property: US and Japan Comparisons, National Center for Industrial Property Information and Training (INPIT), Tokyo.

Chesbrough, H., W. Vanhaverbeke, and J. West (2006), Open Innovation: Researching a New Paradigm, Oxford University Press.

Clark, J., J. Piccolo, B. Stanton, and K. Tyson (2000), Patent Pools: A Solution to the Problem of Access in Biotechnology Patents? United States Patent and Trademark Office (USPTO).

DRI Capital (2008), DRI Capital Launches Structured Finance Fund, DRI

Capital,www.dricapital.com/show_info.php?page_id=31.

eBay (2008), eBay inc. and MercExchange, L.L.C. Reach Settlement Agreement, eBay, http://investor.ebay.com/releasedetail.cfm?releaseid $=296670$.

EC (European Commission) (2007), Communication from the Commission to the European Parliament and the Council - Enhancing the patent system in Europe, EC, Brussels.

EC (European Commission) (2008), Communication from the Commission to the European Parliament, the Council and the European Economic and Social Committee - An Industrial Property Rights Strategy for Europe, EC, Brussels.

EPO (European Patent Office) (2007), Scenarios for the Future, EPO, www.epo.org/topics/patentsystem/scenarios-for-the-future.html. 
FTC (Federal Trade Commission) (2003), To Promote Innovation: The Proper Balance of Competition and Patent Law and Policy, www.ftc.gov/os/2003/10/innovationrpt.pdf.

FTC (Federal Trade Commission) (2008), Public Hearings Concerning the Evolving Intellectual Property Marketplace, www.ftc.gov/os/2008/11/P093900ipwkspfrn.pdf.

Gray, C. (2008), “A New Era in IP Licensing: The Unit License Right Program”, The Licensing Journal, Vol. 28, No. 10, pp. 27-32, Aspen publishers, NY.

Hagel, J. and J.S. Brown (2009), “The Next Wave of Open Innovation”, Business Week, 8 April 2009, McGraw-Hill, www.businessweek.com/innovate/content/apr2009/id2009048_360417.htm.

Hansell, S. (2009), “Trolling for Patents to Fight Patent Trolls”, The New York Times, 30 March 2009, NY.

INCJ (Innovation Network Corporation of Japan) (2009), A new initiative to drive next-generation businesses, INCJ, Tokyo.

IPotential (2009), Brokerage Brochure Website, http://ipotential.com/brokerage/IPotential_Brokerage_2009_color.pdf, accessed 12 October 2009.

IPXI (Intellectual Property Exchange International) (2009), Unit License Rights Contract Market, IPXI, www.ipxi.com/ipxi/doc/ULR\%20Transaction\%20Overview.pdf, accessed 12 October 2009.

IV (Intellectual Ventures) (2009), Invention Company, Intellectual Ventures, Opens Bellevue Laboratory, May 2009, IV.

JPO (Japan Patent Office) (2008a), New Intellectual Property Policy for Pro-Innovation: Intellectual Property System as Global Infrastructure, JPO, www.jpo.go.jp/torikumi_e/puresu_e/pdf/press_new_intellectual_property_policy/report_e.pdf.

JPO (Japan Patent Office) (2008b), Annual Report 2008, JPO, Tokyo.

Keeler, R. (2008), “Turbulent times - patent opportunities”, Financial Times, 30 December 2008.

Klee, K. (2009), "Playing defense on patents”, The Deal Magazine, June 2009, the Deal, LLC.

Lakhani, K.R., L.B. Jeppesen, P.A. Lohse, and J.A. Panetta (2007), "The Value of Openness in Scientific Problem Solving", Harvard Business School Working Paper, No. 07-050, Harvard University, http://hbswk.hbs.edu/item/5612.html.

Malackowski, J.E. (2009), "FTC Hearings on Developing Business Models and a National IP Economic Infrastructure", presentation at FTC (Federal Trade Commission) Public Hearings Concerning the Evolving Intellectual Property Marketplace, 17 April 2009, Washington, D.C.

McAfee (2009), Annual Report 2008, McAfee,http://files.shareholder.com/downloads/MFE/746650748x0x282163/0076BD26-5B7B4C1A-BBCF-1DB7781195A9/McAfee_Annual_Report.pdf.

METI (Ministry of Economy, Trade and Industry) (2007), Interpretive Guidelines on Electronic Commerce and Information Property Trading, METI, Tokyo. 
Millien, R. and R. Laurie (2007), A Summary of Established \& Emerging IP Business Models, The Sedona Conference, Phoenix, AZ.

Millien, R. and R. Laurie (2008), "Meet the middlemen", Intellectual Asset Management (IAM) Magazine, February/March 2008, issue 28, Globe White Page Ltd.

Monk, A.H.B. (2009), "The emerging market for intellectual property: drivers, restrainers, and implications", Journal of Economic Geography, 2009, Vol. 9, Issue 4, pp. 469-491, Oxford University Press.

OECD (2004), Patents and Innovation: Trends and Policy Challenges, OECD, Paris.

OECD (2006), Science, Technology and Industry Outlook 2006, OECD, Paris.

OECD (2008), Open Innovation in Global Networks, OECD, Paris.

OIN (Open Invention Network) (2009), Open Invention Network Extends the Linux Ecosystem as TomTom Becomes Licensee, OIN.

OTL (Stanford University Office of Technology Licensing) (2008), Annual Report 2007-2008, OTL, http://otl.stanford.edu/about/resources/otlar08.pdf.

Page, N. (2009), "IV shifts gear", Intellectual Asset Management (IAM) Magazine, Issue 36, July/August 2009, Globe White Page Ltd.

Palmisano, S.J. (2006), “The Globally Integrated Enterprise”, Foreign Affairs, Vol. 85, No. 3, Council on Foreign Relations, pp. 127-136.

RIM (Research in Motion) (2009), Research In Motion and Visto sign definitive agreement to settle outstanding litigation, RIM, http://press.rim.com/release.jsp?id=2432.

Royalty Pharma (2009a), Royalty Pharma Financial Capabilities Website, www.royaltypharma.com/overview/capabilities.html, accessed 12 October 2009.

Royalty Pharma (2009b), Royalty Pharma Case Studies Website, www.royaltypharma.com/casestudies/institutional/cs-msk.html, accessed 12 October 2009.

Sandhu, A. (2009), “A new approach to intellectual property”, Nature Nanotechnology, Vol. 4, January 2009, Macmillan Publishers Limited.

Seyfer, J. (2007), "Private Equity Helps Fuel IP Wars”, Law.com., 28 June 2007.

Shapiro, C. (2001), "Navigating the Patent Thicket: Cross Licenses, Patent Pools, and Standard-Setting", in Jaffe, A. et al. eds., NBER Innovation Policy and the Economy, pp. 119- 150, MIT Press, Cambridge, MA.

TB Alliance (2008), A Global Effort to Reduce the Costs of a TB Drug Candidate, TB Alliance, www.tballiance.org/newscenter/view-brief.php?id=822, accessed 12 October 2009.

The Economist (2009), "A market for ideas: A pioneering "innovation marketplace" is making steady progress", The Economist, September 19th 2009, The Economist Newspaper Limited. 
Thumm, M. (2008), “Talking tactics: Business Strategies for the Modern Organization”, Patent World, Issue No.202, May 2008, pp. 31-33.

USPTO (United States Patent and Trademark Office) (2007), 2007-2012 Strategic Plan, USPTO, www.uspto.gov/web/offices/com/strat2007/stratplan2007-2012.pdf.

Vardi, N. (2007), Patent Pirates, Forbes, www.forbes.com/free_forbes/2007/0507/044.html.

Yurkerwich, D. (2008), "Patent sales and the IP business plan", Licensing in the Boardroom 2008, Globe White Page Ltd.

Warda, J. (2006), “Tax Treatment of Business Investments in Intellectual Assets, An International Comparison”, OECD Science, Technology and Industry Working Papers, 2006/4, Directorate for Science, Technology and Industry, OECD, Paris, www.oecd.org/sti/wprking-papers.

Watson, R. (2008), A Problem Shared Is a Problem Solved, Fast Company, 8 July 2008. 